\title{
FORESEEING IS BELIEVING: COMMUNITY IMPOSITION OF LIABILITY FOR THE ACTS OF "DANGEROUS" FORMER MENTAL PATIENTS* .
}

\author{
BRUCE S. LEDEWITZ†
}

I

\section{INTRODUCTION}

When is a person or group foreseeably dangerous for purposes of tort law? The Michigan Supreme Court concluded in 1975 in Samson v. Saginaw Professional Building, Inc. ${ }^{1}$ that the possibility is foreseeable that persons who have been involuntarily committed to mental hospitals and then released ("ex-patients") ${ }^{2}$ will commit criminal acts. ${ }^{3}$ For this reason, a commercial landlord who rented space to an out-patient clinic without taking any precautions was liable for the intentional tort of an ex-patient who was being treated at the clinic. Commentators who have discussed this case have emphasized its importance to developing landlord-tenant law. ${ }^{4}$ The purpose of this article is to examine, instead, the decision to consider ex-patients foreseeably dangerous, and to discuss the relationship of that decision to the deinstitutionalization movement. ${ }^{5}$

Copyright (C) 1983 by Law and Contemporary Problems

* I would like to express my thanks to Neil Gotanda, Kenneth Hirsch, Cornelius Murphy, and Robert Taylor for their comments upon an earlier draft. I would also like to thank Deborah Lux, my research assistant, for her valuable assistance.

$\dagger$ Associate Professor of Law, Duquesne University School of Law.

1. 393 Mich. 393, 224 N.W.2d 843 (1975).

2. I do not distinguish in this article between the foreseeable dangerousness, vel non, of the mentally ill and the mentally retarded (or developmentally disabled). The court of appeals majority in Samson, however, seemed to assume that the mentally retarded would not be considered foreseeably dangerous. 44 Mich. App. 658, 663, 205 N.W.2d 833, 836 (1973).

3. 393 Mich. at 404-05, 224 N.W.2d at 848.

4. Bazyler, The Duty to Provide Adequate Protection: Landowners' Liability for Failure to Protect Patrons From Criminal Attack, 21 ARIZ. L. REV. 727 (1979); Note, Commercial Landlord's Liability for Criminal Acts of Third Party, 22 WAyne L. REv. 1483 (1976) [hereinafter cited as Commercial Landlord]; Note, The Duty of a Landlord to Exercise Reasonable Care in the Selection or Retention of Tenants, 30 STAN. L. REV. 725 (1978) (hereinafter cited as Tenant Selection ]; Recent Developments, Samson v. Saginaw Professional Building, Inc.: The Landlord's Duty to Protect Against Crimes By Tenants and Their Invitees, 62 VA. L. REV. 383 (1976) [hereinafter cited as Recent Developments]. Cf. Henszey \& Weisman, What is the Landlord's Responsibility for Criminal Acts Committed on the Premises.?, 6 Real EsT. L.J. 104 (1977).

5. The Samson case raises several issues that will not be discussed here. The Samson court blithely imposed a responsibility of security upon a commercial, as opposed to a residential, landlord. See Commercial Landlord, supra note 4, at 1487. The court imposed rather an open-ended responsibility for security. Cf. Goldberg v. Housing Auth., 38 N.J. 578, 186 A.2d 291 (1962). The obligation of the landlord to investigate tenants' backgrounds might follow from Samson. See Bazyler, supra note 4, at 743-44. Cf. Tenant Selection, supra note 4, at 753-54. These issues, while very significant, are not the focus of discussion here. The court 
In an era of deinstitutionalization of the mentally $i l l,{ }^{6}$ it is not surprising that the issue of the danger of ex-patients arises in tort law. For a variety of reasons, ${ }^{7}$ there have been recent trends both to restrict admissions to state institutions by treating many mental health problems in the community and to release into the community many patients who had been residing in state institutions. ${ }^{8}$ Although deinstitutionalization has its critics, ${ }^{9}$ normalization remains an important goal of all present mental health policy. ${ }^{10}$ The process of normalization includes group residences, other supportive environments, and independent residential living. ${ }^{11}$

indicated that it is negligent for a landlord to fail to take reasonable precautions against foreseeably dangerous conditions on his premises. 393 Mich. at 405-06, 224 N.W.2d at 848-49. The characterization of expatients as dangerous is the part of the decision that draws into question the relationship between tort law and deinstitutionalization.

6. See genetally General Accounting Office, Returning The Mentally Disabled To The COMmunity: Government NeEdS TO DO MORE (1977) [hereinafter cited as GAO REPORT]; Rapson, The Right of the Mentally IIl to Receive Treatment in the Community, 16 Colum. J.L. \& SOC. PROBS. 193 (1980); Note, Zoning For The Mentally IIl: A Legislative Mandale, 16 HARV. J. Legis. 853 (1979) [hereinafter cited as Zoning]. Much of the discussion of deinstitutionalization has emphasized the problems of the mentally retarded. See, e.g., V. Bradley, Deinstitutionalization of Developmentally Disabled Persons (1978); D. Braddock, Opening Closed DoOrs (1977); R. Scheerenberger, DeinstitutionalizaTION AND Institutional Reform (1976); Comment, Exclusionary Zoning and Its Effects On Group Homes In Areas Zoned For Single-Family Dwellings, 24 KAN. L. REV. 677 (1976) [hereinafter cited as Group Homes]. Despite earlier attempts at deinstitutionalization, see A. Deutsch, ThE MENTALly Ill IN AMERICA (1949), the present movement is usually associated with President Kennedy's message to Congress in 1963 on mental illness and mental retardation, 1963 U.S. CODE CoNG. \& AD. News 1466 (Feb. 5, 1963); see GAO REPORT, supra, at 2, and the development of critiques of mental health practices in the early 1960's, such as T. Szasz, The Myth of Mental Illness (1961), T. Szasz, Law, Liberty and Psychiatry (1963), and E. GofFMAN, Asylums (1962). See Bazelon, Institutionalization, Deinstitutionalization and the Adversary Process, 75 Colum. L. REv. 897 n.1 (1975); Rapson, supra, at 198 n.26. Cf. T. SzASz, THE MYTH OF PSychotheraPy 165 (1978); Zoning, supra.

7. One reason given for the growth of deinstitutionalization is the availabilty of psychotropic drugs that lessen the severity of certain behavior patterns associated with mental illness. See, e-g., Zoning, supra note 6 , at 855-56. Other reasons include the perceived conditions of many public mental hospitals, see Chambers, Altematives to Civil Commitment of the Mentally IIl: Practical Guides and Constitutional Imperatives, 70 MICH. L. REV. 1107, 1125-50 (1970), a fear of unjustified commitments, see Brooks, The Impact of Law on Psychiatric Hospitalization: Onslaught or Imperative Reform?, in NEW DiREcTIONS FOR MENTAL HEALTH SERVICES, 13, 15-17 (S. Halleck ed. 1979), a growing belief in the advantages of treatment in the community setting, see Shuman \& Hawkins, The Use of Aliematives to Institutionalization of the Mentally Ill, $33 \mathrm{Sw}$. L. J. $1181,1182(1980)$, and a desire to save money, see Bazelon, supra note 6, at 907.

8. Between 1958 and 1973 , the population of state mental hospitals dropped by 300,000 . S. REP. NO. 198, 94th Cong., 1st Sess. (1975), reprinted in 1975 U.S. CODE CONG. \& AD. NEws 469, 540. It has been estimated that by 1979 , three-quarters of all persons who were receiving mental health care were being treated as out-patients. Id. ; see also F. NeUman, CARING 49 (1980).

9. Critics argue that deinstitutionalization has the effect of reducing the level of services to the mentally ill. See, e.g., Santiesteven, Out of Their Beds and Into the Streets (1975); A. Scull, Decarceration, Community Treatment and the Deviant: A Radical View (1977); Feldman, The Legal Restraints on Psychiatric Care, 1980 Legal Med. 221, 224; Frohboese \& Sales, Parental Opposition to Deinstitutionalization, A Challenge in Need of Attention and Resolution, 4 LAW \& HUM. BEHAV.1 (1980); Pule \& Palmer, Patient Rights and Patient Chronicity, 8 J. Psychiatry \& LAW 59 (1980).

10. See J. MORRICE, CRISES INTERVENTION, 6 (1976) ("[r]he large old mental hospital stands as a monument to the folly of cutting off patients from their families and their communities"). The term normalization is often used in literature dealing with the mentally retarded. See D. BRADDOCK, supra note 6 , at 3-7; V. BRADLEY, supra note 6, at 5, 17; R. SCHEER ENBERGER, supra note 6, at 73-75; Hopperton, $A$ Slate Legislative Strategy For Ending Exclusionary Zoning of Community Homes, 19 URB. L. ANN. 47 (1980); Group Homes, supra note 6 , at 679-80. The goals of programs for the mentally retarded, however, do not differ significantly from those programs for the mentally ill. See Kaplin, State Control of Deviant Behavior: A Critical Essay on Scull's Critique of Community Treatment and Deinstitutionalization, 20 ARIz. L. REV. 189, 218-29 (1978); Shuman \& Hawkins, supra note 7 , at 1181-82.

11. See Zoning, supra note 6 , at 856 . 
Thus, the response of landlords to attempts by ex-patients to rent apartments or to clinics' attempts to lease space, as in Samson, is likely to be a recurring issue.

Deinstitutionalization of mental patients has led to a debate about the threat of harm that is presented by ex-patients living in the community. ${ }^{12}$ The capacity of psychiatrists to predict future violent actions has been challenged. ${ }^{13}$ Critics suggest that psychiatrists tend to over-predict dangerousness; ${ }^{14}$ but, in the context of deinstitutionalization the psychiatrist has judged the patient not likely to be violent in the future. The problem then becomes the accuracy of that determination. There is not extensive literature documenting the inaccuracy of psychiatric prediction of nonviolence. ${ }^{15}$ Nor is it clear that deinstitutionalization has increased the number of torts and crimes that are perpetrated. ${ }^{16}$ Nevertheless, the issue of harms caused by ex-patients, especially those with histories of violence, remains open to debate. ${ }^{17}$ The resolution of liability in Samson should be evaluated in the context of the debate over the foreseeability of danger. This paper will argue that Samson represents an unjustifiable judicial infringement of legislative prerogative. The determination that all or most mental patients are foreseeably dangerous threatens deinstitutionalization. Samson and other tort cases dealing with alleged dangerous groups or persons make that determination by reference to a community judgment of the acceptability of certain persons or groups. This approach, which is illustrative of Professor George Fletcher's tort paradigm of reciprocity, minimizes unduly the role of the legislature in defining the acceptability

12. One expression of community fear of the mentally ill is the frequent opposition to the establishment of group residences. See Brestin, Backlash Against the Disabled, 4 MeNT. HEALTH Dis. RPTR. 345-55 (1980); Zoning, supra note 6, at 858-59; Comment, Exclusionary Zoning of Community Facilities, 12 N.C. CENT. L.J. 167 (1980) (mentally retarded). Part of this fear may be due to the assumption that the mentally ill are dangerous. See F. NEUMAN, supta note 8, at 67.

13. See, e.g., K. Miller, Managing Madness, The Case Against Civil Commitment, 57-65 (1976); F. Neuman, supra note 8, at 68; Ennis \& Litwack, Psychiaty and the Presumption of Expertise: Flipping Coins in the Courtroom, 62 CALIF. L. REV. 693 (1974); Pfohl, The Psychiatric Assessment of Dangerousness: Practical Aroblems and Political Implications, in IN FEAR OF EACH OTHER 77, 78 (1977); Sadoff, Changes in Mental Health Law: Progress for Patients-Problems for Psychiatrists, in New Directions for Mental HeAlTh Sertes 1, 3 (S. Halleck ed. 1979); Note, A New Emancipation: Toward An End To Involuntary Civil Commilments, 48 Notre Dame Law. 1334, 1339 (1973).

14. Psychiatrists are usually criticized for overprediction of violence rather than for random inaccuracy. See, e.g., F. NEUMAN, supra note 8, at 68 ("[psychiatrists] are likely to exaggerate the danger rather than minimize it'); T. Thornberry \& J. Jacoby, The Criminally Insane 26-32 (1979); Dershowitz, Psychiatrists' Power in Civil Commitment, 2 Psychology TODAY 47 (1969).

15. See infra note 17.

16. See Brooks, supra note 7, at 19 ("[b]ut in most cases, retaining patients in the community seems to work out well . . . [especially where community alternatives are considered before hospitalization]"); $\mathbf{F}$. Neuman, supra note 8, at 67; Guze, Woodruff \& Clayton, Psychiatric Disorders and Criminality, reported in edited form in READINGS IN LAW AND PSYCHIATRY 329 (1975). Attempts have been made to show that even release of those mental patients who have been adjudged dangerous does not lead to significant increases in the level of violent activity in the community. See T. THORNBERRY \& J. JACOBY, supra note 14. The assumption that incapacitation of violent offenders of all types reduces the level of criminal activity has been subject to challenge. See Van Dine, Dinitz \& Conrad, The Incapacitation of the Dangerous Offender: A Statistical Experiment, in IN FEAR OF EACH OTHER 103 (1977).

17. "Whether there is a correlation between mental illness and crime and violence (i.e. whether the mentally ill as a group are more prone than the general public to violence, given identical environments) remains an unanswered question." Zoning, supra note 6, at 860 (citations omitted). The presence of a prior criminal record among some ex-patients may increase the likelihood of future violence. See id. at $n .34 ; K$. MiLler, supra note 13, at 57-65; Tenant Selection, supra note 4, at $747 \mathrm{n} .74$ and sources cited therein. 
of deinstitutionalization. There is an alternative to Samson liability, which I will call professional liability, that "fine-tunes" legislative choice of deinstitutionalization, rather than undermines it, and thus represents a more appropriate judicial resolution of liability issues such as those in Samson.

II

Samson v. Saginaw Professional Building, InC.

The facts in Samson are as follows. Carol Samson was employed as a secretary for a lawyer on the fifth floor of the Saginaw Professional Building, which was owned by Saginaw Professional Building, Inc. ${ }^{18}$ On the fourth floor the defendant had rented space to the Saginaw Valley Consultation Center, a clinic operated by the Michigan Department of Mental Health, which provided outpatient care for "released mental patients." 19 The center treated up to twenty-five patients a day, one of whom was Donald Butzin.

On March 30, 1966, Samson left her office to go to a coffee shop on the first floor. She entered the elevator. Butzin also got on. When the elevator started down, Butzin pressed the emergency stop button, produced a knife and took Samson's wallet. Butzin then began to stab the victim. He also stabbed himself, which apparently led him to restart the elevator and flee. ${ }^{20}$

Samson and her husband sued Butzin and the landlord, Saginaw Professional Building, Inc. The jury awarded $\$ 60,000$ to Carol Samson and $\$ 492$ to her husband. ${ }^{21}$ The Michigan Court of Appeals and Michigan Supreme Court affirmed. ${ }^{22}$ The courts were closely divided and there were fully developed dissents. ${ }^{23}$

Butzin, who was sixteen at the time of the assault, had engaged in violent behavior on one prior occasion. In January 1963 he had entered a woman's home and slashed the woman as she tried to escape. Butzin was sent to a juvenile home for a few months and then released to his parents. In July 1963 he was committed to Traverse City State Hospital where he remained until he was placed on convalescent leave in June 1964. From June 1964 until the assault in March 1966, Butzin was treated approximately once a week at the Saginaw Valley Consultation Center, apparently without incident. ${ }^{24}$

The Center had moved to the Saginaw Professional Building in January 1965. Between January 1965 and March 1966 there had not been any assaultive acts committed in the building by any patient of the Center; ${ }^{25}$ nor, for that matter, did

18. 393 Mich. 393, 398, 224 N.W.2d 843, 845 (1975).

19. 44 Mich. App. 658, 672, 205 N.W.2d 833, 840 (1973) (Danhof, J., dissenting).

20. Id.

21. 393 Mich. at 411,224 N.W.2d at 851 (Levin, J., dissenting).

22. 44 Mich. App. 658, 205 N.W.2d 833 (1973), affd, 393 Mich. 393, 224 N.W.2d at 843 (1975). Butzin did not appeal.

23. The decision in the Court of Appeals was two to one. 44 Mich. App. at 671, 205 N.W.2d at 840 (Danhof, J., dissenting). The decision in the supreme court was four to three. 393 Mich. at 411,224 N.W.2d at 851 (Levin, J., dissenting).

24. 393 Mich. at 412,224 N.W.2d at 851 (Levin, J., dissenting).

25. Id. 
either court's opinion suggest that there had been threatening behavior or any hostile act by any ex-patient in the building. The landlord's leasing agent and its principal stockholder, however, had both received complaints about the "poor dress" of patients at the Center and about their use of the stairs and elevators to reach the fourth floor. ${ }^{26}$

In considering the landlord's liability, the court noted that a landlord owes his tenants a duty of protection against unreasonable risks of physical harm. ${ }^{27}$ Thus a landlord, unlike others, may be required to act after observing danger to tenants even if that danger consists of a threat by other persons. ${ }^{28}$ The court set forth two tests for negligence, both of which must be satisfied before liability may be assessed against a landlord. These tests required, first, that the risk of harm be foreseeable, ${ }^{29}$ and second, that the risk be unreasonable. ${ }^{30}$ "Unreasonable" is used by the court to mean that the defendant's action or omission, compared to the foreseeable risk, is deemed an unreasonable response. ${ }^{31}$ The court found both a foreseeable risk of harm and an unreasonable response. ${ }^{32}$

On what basis did the court determine that there was a foreseeable risk of harm? The court did not discuss foreseeable risk in terms of general probabilities such as the possibility that any tenant might assault another tenant. ${ }^{33}$ Nor was risk in this case based on the likelihood that any individual ex-patient might assault someone else. The court indicated that the landlord's liability in this case

26. 44 Mich. App. at 663,205 N.W.2d at 836 . There was one complaint, which was lodged on behalf of "females working in the buildings." $I d$.

27. 393 Mich. at 407,224 N.W.2d at 849.

28. Id. at 406,224 N.W.2d at 849 . The court in Samson did not distinguish between liability for foreseeable criminal acts of third parties that is based upon a special relationship, and liability based upon the decision affirmatively to bring foreseeably dangerous persons into contact with the public. The court, however, quoted with approval RESTATEMENT (SECOND) OF TORTS § 302B comment e (1965), which treats such an affirmative act as an alternative to liability based upon the existence of a special relationship. 393 Mich. at 403, 224 N.W.2d at 847. Subsection D further defines such an affirmative act as bringing the foreseeably dangerous person into "contact or association" with others "under circumstances which afford a peculiar opportunity or temptation for . . . misconduct." Under such a theory, anyone fostering contact with ex-patients might be liable for failing to protect others from harm by an ex-patient.

29. 393 Mich. at 404,224 N.W.2d at 848 .

30. Id.

31. Id. at 406-07, 224 N.W.2d at 849. "The low probability [of harm], however, must be balanced against the magnitude of the potential harm involved to determine whether or not inaction under these circumstances is reasonable."

32. Samson does not uphold a doctrine of strict liability once the decision to rent to the Center was made. The landlord in Samson took no security precautions at all; the court discussed precautions that might have been taken. Id. at 408-410,224 N.W.2d at 850-51. A jury is free to find that a future commercial landlord took all reasonable precautions, and thus was not negligent. There is even some language in the opinion suggesting that the decision to rent may not itself be considered the basis for liability. Id. at 407, 224 N.W.2d at 849 ("[f]or this act, by itself, our law imposes no liability, and indeed should impose none"). On the other hand, the risk that is deemed to be foreseeable, "that of a criminally insane person running amok within an office building filled with tenants and invitees . .," id. at 408, 224 N.W.2d at 849 , seems so serious that it is hard to imagine a court overruling a jury decision in any future case that the landlord's precautions were insufficient. The court emphasized that the reasonableness of the landlord's response is a question for a jury. Id. at 408-09, 224 N.W.2d at 850 . The prudent landlord therefore should anticipate liability whenever an ex-patient who is on the premises with the landlord's permission intentionally harms another tenant or invitee. See infra text accompanying note 48 . Of course liability for an intentional tort may be great because the injury may be severe.

33. The "risk" was characterized by the court as "that of a criminally insane person running amok" rather than as a tenant committing an assault. 393 Mich. at 408,224 N.W.2d at 849. 
did not derive from specific knowledge about the ex-patients or their histories. ${ }^{34}$ The lack of inquiry made by the landlord into the character of the ex-patients was not the critical factor in the court's decision; after stating that a failure to inquire could be a basis for liability, ${ }^{35}$ the court went on to hold that even if an agent of the landlord in this case had inquired and had been told nothing about the persons being treated, the landlord was still under an obligation "to provide some security measures" by virtue of the presence of ex-patients at the Center. ${ }^{36}$ Thus it was on the basis of ex-patient status itself that the court determined that there was a foreseeable risk of harm: ex-patients require security measures because they represent "a possible dangerous condition." 37 The court found that the risk of harm from ex-patients was foreseeable because other tenants had indicated "concern and uneasiness," unrelated to any actual behavior, ${ }^{38}$ over the presence of the expatients. $^{39}$

The opinion says very little about why ex-patients, as opposed to all tenants, may be considered foreseeably dangerous by a jury. The court acknowledged that the risk of an attack by an ex-patient might be small. ${ }^{40}$ That low probability was balanced against the magnitude of the harm that would result from "a criminally insane person running amok within an office building."41 It might be said of all tenants, however, that there exists a remote possibility that one tenant will begin to attack other people in indiscriminate fashion. ${ }^{42}$ Nevertheless, there does not appear to be any obligation on the part of a landlord to take security measures against all tenants. ${ }^{43}$ Whatever the reasons for the determination that ex-patients are foreseeably dangerous, the implications of that decision for deinstitutionalization are all too clear.

34. Id. at $408-09,224$ N.W.2d at 850 .

35. Id. at $407-08,224$ N.W.2d at $849-50$.

36. Id. at $408-09,224$ N.W.2d at 850 .

37. Id. at 411,224 N.W.2d at 851 (addendum). "All my opinion says is that when the landlord is informed by his tenants that a possible dangerous condition exists in the building, he has a duty to investigate and take available preventive measures."

38. Id. at 404-05, 224 N.W.2d at 848. There is no indication that any overt, hostile behavior by any ex-patient brought on these complaints.

39. The supreme court also affirmed without comment the evidentiary ruling of the court of appeals that Butzin's probate record and the testimony of the prior assault victim were admissible. Id. at 409, 224 N.W.2d at 850 . The court of appeals decided that though Butzin's history was not available to the landlord, the landlord could have discovered that persons with a propensity for violence would be present. 44 Mich. App. at 770-71, 205 N.W.2d at 839-40. The majority presumably meant that the landlord could have discovered that persons with a history of violence similar to that of Butzin would be present at the Center. See id. at 665, 205 N.W.2d at 837 ("Butzin . . . was representative . . .").

40. 393 Mich. at 406,224 N.W.2d at 849.

41. Id. at $406-08,224$ N.W.2d at 849 .

42. There is always a possibility that any tenant will assault another tenant. See F. NEUMAN, supra note 8 , at 68 .

43. There is no indication in the opinion that notice of the presence of tenants who are not ex-patients should lead a landlord to investigate and take action. See supra note 32. Cf. Recent Developments, supra note 4, at 402-03 (Samson duty extends to tenants whom landlord should know have a prior criminal record). 


\section{III}

\section{EVAluation of SAMSON LiabiLITy}

\section{A. Consequences of Samson Liability}

The rule of liability established in Samson, which asserts that ex-patients as a group are foreseeably dangerous, should be distinguished from a generalized landlord liability rule. Under a generalized tort rule, landlords could be held liable for intentional torts committed by any person on their premises. A landlord in such a world would seek tenants who were unlikely to commit intentional torts. ${ }^{44}$ If he believed that ex-patients were more likely to commit such torts than were other people, and if he believed further that the tendency to commit such torts was high, he would seek to exclude ex-patients as tenants, or at least to satisfy himself that a particular ex-patient to whom he was considering renting did not have this tendency. On the other hand, if he believed that ex-patients were not unusually likely to commit such torts, or if he did not have an opinion, he would tend to treat them as he would treat all other tenants. Because such a generalized rule of liability would permit landlords the option of treating ex-patients like other individuals, it would not necessarily exclude ex-patients from the rental market.

Samson liability differs from this hypothetical rule in that only a certain group of tenants impose liability on the landlord for their intentional torts. ${ }^{45}$ Under such a liability rule, even if, in fact, ex-patients commit only an average number of intentional torts, the landlord must still react differently to ex-patients than to others as tenants because the landlord is potentially liable for an ex-patient's tort. Even if the landlord is convinced that ex-patients are a reasonably nondangerous group, he still faces increased potential liability for renting to them. The direct consequences of Samson liability are therefore an increased risk of suit and increased costs for landlords who permit any ex-patients or ex-patient-related facilities on their property.

In turn, the likely indirect consequence of this increased cost is unwillingness by landlords in both commercial and residential ${ }^{46}$ contexts to rent to ex-patients. ${ }^{47}$

44. I do not claim that all landlords necessarily would act on wealth maximizing principles alone. It may be that some landlords would seek out ex-patients in order to help them find decent housing. It might also be that the liability rule would be imposed in such haphazard fashion that reliable forecasts would be impossible. On the other hand, if the rule were known, and insurance companies might consider it important to know about such rules and communicate them to their insureds, it seems likely that many landlords would seek to reduce this cost, as they strive to reduce other costs. It is certainly true that many tort law theorists assume that tort rules generate wealth maximizing responses. See, e.g., Dernsetz, When Does the Rule of Liability Matter?, 1 J. Legal Stud. 13 (1972); W. Prosser, The LaW of Torts 23 (1971) Calabresi \& Hirschoff, Toward A Test For Strict Liability in Torts, 81 Yale L.J. 1055 (1972).

45. I assume that Samson liability would apply with equal force to a residential landlord who rented to ex-patients. The duty to act, which the court regarded as a prerequisite to liability was defined by the court as "some sort of relationship between the actor and the other party which the law or society views as sufficiently strong to require more than mere observation of the events which unfold on the part of the defendant." 393 Mich. at 406, 224 N.W.2d at 849 . The very fact that the court regarded Samson as an invitation to "revisit" Johnston v. Harris, 387 Mich. 569, 198 N.W.2d 409 (1972), which involved the liability of a residential landlord, 393 Mich. at 427, 224 N.W.2d at 847, indicates that residential landlords are also in a sufficiently strong relationship to tenants to justify imposition of a duty to take reasonable precautions to protect tenants from foreseeably dangerous conditions.

46. See supra note 45.

47. See Recent Developments, supra note 4, at 403-11; Tenant Selection, supra note 4, at 730 n.17. 
The landlord, in order to avoid personal liability, must either install an effective security system ${ }^{48}$ or obtain insurance against the risk. ${ }^{49}$ If these precautions are expensive, ex-patients or those who care for them probably will not be able to pay extra rent for them. ${ }^{50}$ Moreover, other tenants may well decide not to pay for such precautions by choosing to live in buildings from which ex-patients are excluded. ${ }^{51}$ Without the ability to pass on additional costs, landlords will seek to exclude expatients and related facilities. ${ }^{52}$ Thus, one likely outcome of the application of Samson liability is increased residential concentration of ex-patients. ${ }^{53}$ Further-

48. The court suggested the posting of warnings, 393 Mich. at $408-09,224 \mathrm{~N} . \mathrm{W} .2 \mathrm{~d}$ at 850 , or the relocation of the Center to the first floor, id. at $410,224 \mathrm{~N} . \mathrm{W} .2 \mathrm{~d}$ at 851 , in addition to the more expensive precaution of posting guards on the elevators. Id. While the former precautions would not burden the landlord greatly, such precautions might very well not seem sufficient to a jury; nor might relocation prove practical. See Recent Developments, supra note 4, at 406-07.

There is doubt that any precaution would prove sufficient in the end. Cf. supra note 32 . The court was careful to note that liability was not being imposed for the decision to lease space to the Center. $393 \mathrm{Mich}$. at 407, 224 N.W.2d at 849. Nevertheless, in the court's view, the landlord created the danger by his decision to rent to ex-patients. It seems anomalous that the landlord would be free to create a dangerous condition and then escape liability because of the provision of a security system that did not succeed in preventing harm. See generally Tenant Selection, supra note 4. But see Bazyler, supra note 4, at 750-54. Whether the liability rule in Samsan evolves into a type of strict liability once the decision to rent is made or remains a tort based upon reasonable precautions is a subject beyond the scope of this article. It should be noted, however, that two sources of authority in the area of dangerous persons discussed within, the negligent employment cases and the control cases, illustrate, respectively, these distinct approaches to liability. See infra notes 109-139 and accompanying text. As long as a jury decides whether the precautions taken were reasonable, the difference between strict liability and negligence analysis may prove more important in theory than in outcomes of actual cases in which innocent parties are hurt and no other recovery seems likely. See The 7735 Hollywood Boulevard Venture v. Superior Court, 119 Cal. App. 3d 901,172 Cal. Rptr. 528, 530 (1981) ("grossly unfair" to permit jury to determine that security was "inadequate" especially since in the contest precautions had proven ineffective).

49. Of course these two precautions are not unrelated. An insurance company might well condition the size of the premium upon the effectiveness of the security system. See Recent Developments, supra note 4, at 404-05.

Indemnification agreements are possible as alternatives to insurance, but seem an unlikely outcome. Ex-patients would not be viewed as reliable guarantors, and an institution like the Center would probably choose to leave a building rather than pay the increased costs. See infra note 50 .

50. Nor is it likely that an institution like the Center in Samson, which presumably could pay for the added cost of security precautions, would choose to expend its limited resources in this way. See Recent Developments, supra note 4 , at $408-10$.

51. See id. at 408-09. The lawfulness of landlords' attempts to exclude ex-patients from their buildings is an issue beyond the scope of this article. See Rehabilitation Act of 1973, Pub. L. No. 93-112, §504; 87 Stat. 394 (codified as amended at 29 U.S.C. $\$ 794$ (Supp. III 1979)), which prohibits discrimination against handicapped persons in any program or activity receiving federal financial assistance; Majors v. Housing Auth., 652 F.2d 454 (5th Cir. 1981); Note, Mental Illness: A Suspect Classification?, 83 Y ALE L.J. 1257 (1974). Attempts by a landlord even to ascertain mental background may be subject to challenge. $C f$. Doe v. Syracuse School Dist., 508 F. Supp. 833 (N.D.N.Y. 1981). Even were a prohibition against discrimination applied against a particular landlord, however, the landlord would not necessarily be prohibited from attempting to recover judicially imposed security costs from ex-patients alone, despite the impact of such added costs upon the ability of ex-patients to live in certain buildings. Cf. Southeastern Community College v. Davis, 442 U.S. 397 (1979).

52. Such exclusion could be accomplished directly, by avoiding such leases, or indirectly, by setting rent sufficiently high to recoup projected security and insurance costs. See supra note 51.

53. It has been widely noted that deinstitutionalization can lead to highly concentrated pockets of expatients living in run-down buildings catering exclusively to formerly institutionalized persons. See, e.g., Rapson, supra note 6, at 209 (referring to "mental illness ghettos"); Zoning, supra note 6, at 854 .

Unfortunately, concentration of ex-patients and institutions serving them may represent a rational response to Samson liability. The costs of liability may be reduced in several ways by such concentration. First, the purchase of insurance and payment of other administrative costs could be reduced per capita when accomplished on a large scale. Second, the procurement of effective security precautions, and thus 
more, if Samson liability is applied to employers ${ }^{54}$ and storeowners, ${ }^{55}$ ex-patients would be likely to have greater difficulty in obtaining employment and services as well.

The potential combination of diminished rental and employment opportunities along with restricted access to goods and services clearly threatens the goals of deinstitutionalization. ${ }^{56}$ Whether that burden on deinstitutionalization represents intelligent public policy and an appropriate judicial intervention depends upon judicial justification for finding ex-patients to be foreseeably dangerous. That justification cannot be understood without first examining the traditional responsibility of landlords to protect their tenants. Landlords have been held to a duty to protect tenants from foreseeable criminal activity by third parties. The existence of any duty on the part of the landlord is a critical component of liability in Samson. The nature of that duty, however, to take reasonable steps to prevent foreseeable criminal acts presents, rather than resolves, the determinative issue in Samson: under what circumstances should the presence of ex-patients be deemed to be a foreseeably dangerous condition?

\section{B. Traditional Landlord Liability}

The decision in Samson has been criticized as an unjustifiable extension of landlord-tenant law. ${ }^{57}$ On the contrary, it should be viewed as consistent with trends

lower costs of insurance or self-insurance, could be rendered economically feasible by the presence of a large number of ex-patients upon whom to spread the cost. Third, ex-patients might prove less likely to sue for damages in the case of attack - a situation the ex-patient may be all too familiar with after experiencing a large-scale mental institution. Finally, although ex-patients may prefer to live away from other expatients, this preference might prove less strong than the similar preference of nonpatients. The "anxiety" loss of rent that a landlord could experience from the introduction of an ex-patient as a tenant could be reduced by identifying a surrounding tenant group less likely to object. Other ex-patients could constitute such a group.

Although all these factors might allow a landlord to charge an ex-patient or clinic lower rent if he rents only to other ex-patients, lower rent by itself would not necessarily lead to concentration of ex-patients. Concentration would result because public funds are limited. Ex-patients who rely upon the state for various forms of social welfare assistance may be expected to seek the lowest rents. See Rapson, supra note 6, at 207-211, 215-16. Clinics serving ex-patients also might respond to such financial incentives. Funds saved as a result of lower rent would be available for services to the mentally ill.

54. As the discussion infra at text accompanying notes 126-128 will indicate, employers have been held liable for the intentional torts of their foreseeably dangerous employees. The Michigan Supreme Court in Samson pointed to the RESTATEMENT (SECOND) OF TORTS \$\$ 314-324A (1965) as illustrative of the relationships that may impose a duty to protect persons from a risk of harm from others. $393 \mathrm{Mich}$. at $406 \mathrm{n} .2$, 224 N.W.2d at 849 n.2. Section 317 includes the duty of an employer under certain circumstances to control the intentional torts of foreseeably dangerous employees. See also RESTATEMENT (SECOND) OF TORTS $\S 302 B$ comment e, example (b) (1965). Cf. supra note 28.

55. While the storeowner category might be considered something of an expansion of Samson liability, see Bazyler, supra note 4, at 735-37, the relationship between storeowner and patron has been recognized as a special relationship which creates a duty to protect patrons from foresecable criminal acts. See, e.g., Mitchell v. Archibald \& Kendall, Inc., 573 F.2d 429, 437 (7th Cir. 1977) (duty of occupier of land limited to invitees "while they are upon the land"); see generally RESTATEMENT (SECOND) OF TORTS § 314A (3) (1965). Cf. Adkins v. Ashland Supermarkets, Inc., 569 S.W. 2 d 698 (Ky. App. 1978) (basic duty of making business premises reasonably safe does not include obligation to comply with demands of armed robbers).

56. Although just being outside a public institution can represent a real benefit for an ex-patient, see Kaplan, supra note 10, at 196-97, adequate housing, job prospects and reasonable access to goods and services are all important in their own right and essential to the process of permanent readjustment to community life. See generally Rapson, supra note 6.

57. See Recent Developments, supra note 4; Commercial Landlord, supra note 4. 
in tort law which extend liability of landlords to crimes committed by unknown third parties. ${ }^{58}$ In two important respects, Samson is characteristic of these cases. First, it was presumed by the court that the landlord has an obligation to protect tenants from harm on his property. Second, the landlord's liability was contingent on the foreseeability of criminal activity.

The first case in Michigan to recognize the obligation of a landlord to protect tenants from the foreseeable criminal acts of third parties was Johnston $v$. Harris. ${ }^{59}$ This case was viewed by the Samson court as the primary basis for its decision. ${ }^{60}$ In Johnston, a tenant was assaulted and robbed in the foyer of his dimly lit unlocked apartment building. The case raised the issue of the applicability to landlords of the general rule that a private party is under no obligation to protect another from criminal acts. ${ }^{61}$ Nevertheless it was assumed by both the court of appeals ${ }^{62}$ and the supreme court that the landlord has a duty to act. ${ }^{63}$

Both courts agreed that there had been a violation of the duty to provide adequate lighting and locks; the determinative issue in the case was whether that violation proximately caused the tenant's harm. ${ }^{64}$ Not surprisingly, the Michigan Supreme Court decided $^{65}$ that the case should be governed by Restatement (Second) of Torts sections $448^{66}$ and $449^{67}$, which define proximate cause by reference to foreseeability. Thus, because "in a high crime district it is reasonably foreseeable that inadequate lighting and unlocked doors would create conditions to which criminals would be attracted to carry out their nefarious deeds," the landlord was held to be liable; the criminal act by an unknown person was not considered a superseding cause of the harm. ${ }^{68}$

58. See Tenant Selection, supra note 4, at 729.

59. 387 Mich. 569, 198 N.W.2d 409 (1972).

60. The supreme court regarded Samson as an opportunity to "revisit" Johnston. 393 Mich. at 402,224 N.W.2d at 847 .

61. See Henszey \& Weisman, supra note 4, at 105 n.5 (1977); Comment, Landlord-Tenant Law: Landlord Held Negligent for Criminal Assault by Third Party Intruder on Tenant, 55 MiNN. L. REV. 1097 (1971).

62. 30 Mich. App. 627, 186 N.W.2d 752 (1971), rev'd, 387 Mich. 569, 198 N.W.2d 409 (1972).

63. "Review of the record in the instant case indicates that plaintiff made a prima facie case that defendant owed a duty to maintain adequate lighting and door locks." 30 Mich. App. at 630, 186 N.W.2d at 753 .

The controlling issue is: where plaintiff has presented a prima facie case to a judge without a jury that a landlord had a duty to provide adequate porch and vestibule lighting and a lock on the front door of his apartment building, was the landlord's breach of that duty a proximate cause of plaintiffs mugging by a criminal who was lurking in the poorly lighted and unlocked vestibule of the apartment building?

387 Mich. at $572-73,198$ N.W.2d at 410.

64. 30 Mich. App. at 630-31, 186 N.W.2d at 753; 387 Mich. at 572, 198 N.W.2d at 410.

65. 387 Mich. at 573-74, 198 N.W.2d at 410 .

66. Restatement (SECOND) OF TORTs $\$ 448$ (1965):

The act of a third person in committing an intentional tort or crime is a superseding cause of harm to another resulting therefrom, although the actor's negligent conduct created a situation which afforded an opportunity to the third person to commit such a tort or crime, unless the actor at the time of his negligent conduct realized or should have realized the likelihood that such a situation might be created, and that a third person might avail himself of the opportunity to commit such a tort or crime.

67. RestatemENT (SECOND) OF TORTS $\$ 449$ (1965): "If the likelihood that a third person may act in a particular manner is the hazard or one of the hazards which makes the actor negligent, such an act whether innocent, negligent, intentionally tortious, or criminal does not prevent the actor from being liable for harm caused thereby."

68. 387 Mich. at 573-74, 198 N.W.2d at 410. 
The outcome in Johnston is part of an ongoing debate concerning the scope of liability of landlords for criminal activity on their premises. Despite some relaxation of the landlord's common law tort immunity for defects in the leasehold, ${ }^{69}$ and despite suggestions that general tort principles rather than formal categories should govern imposition of a duty of protection, ${ }^{70}$ it is probably still the general rule that the landlord-tenant relationship is not regarded as a special relationship that justifies imposition of a duty to protect tenants. ${ }^{71}$ In the leading case of Goldberg $v$. Housing Authority, ${ }^{72}$ the reasons for rejecting the landlord's duty to protect tenants through provision of private police protection included the public nature of the obligation to provide police protection, ${ }^{73}$ the uncertain contours of such a duty, ${ }^{74}$ and the burden of the provision of security measures. ${ }^{75}$ The Goldberg court rejected foreseeability of criminal acts as the basis for establishing a duty of protection because "[e]veryone can foresee the commission of crime virtually anywhere and at any time." 76

Some later decisions have recognized a general duty on the part of landlords to take reasonable steps to protect tenants from criminal acts by unknown third parties. ${ }^{77}$ Consistent with Goldberg, courts have not grounded such a duty on the gen-

69. See Note, Landlord and Tenant-Landlord May be Liable For Theft Afler Suitable Notice of Defective LockBraitman v. Overlook Terrace Corp., 68 N.J. 368, 346 A.2d 76 (1975), 7 Seton Hall L. REV. 683, 685-89 (1976) [hereinafter cited as Note Landlord-Tenant] (explaining historical reasons for absence of tort liability for defects in the leasehold and canvassing some modern exceptions); Commercial Landlord, supra note 4, at 1483-85.

70. See Bazyler, supra note 4, at 737-45. Cf. Weinreb, The Case for a Duty to Rescue, 90 YALE L.J. 247 (1980).

71. See Pippin v. Chicago Housing Authority, 58 Ill. App. 3d 1029, 374 N.E.2d 1055 (1978), affd, 78 Ill. 2d 204, 300 N.E.2d 596 (1979); Cornpropst v. Sloan, 528 S.W.2d 188 (Tenn. 1975); Bazyler, supra note 4 , at 736 (commercial landlords); Note, Landlord-Tenant, supra note 69, at 685; Note, Landlord's Duty to Protect Tenonts from Criminal Acts by Third Parties: The View from 1500 Massachusetts Avenue, 59 GEO. L.J. 1153,1163 (1971) [hereinafter cited as View from Mass. Ave. ]. Cf. Applebaum v. Kidwell, 12 F.2d 846 (D.C. Cir. 1926). Landlords have been held liable for failure to protect tenants from physical defects in common areas, see Lipsitz v. Schecter, 377 Mich. 685, 142 N.W.2d 1 (1966); Recent Cases, Landlord Owes Duty To Provide Protection for Tenants Against Criminal Acts by Third Parties, 24 VAND. L. REV. 195, 196 \& n.5 (1970), but this obligation did not, until recently, lead courts to recognize the landlord-tenant relationship as a special relationship that was viewed as a prerequisite for liability for failing to prevent injury by third parties. See Commercial Landlord, supra note 4, at 1484-85; Recent Developments, Landlord Held to a Duty of Reasonable Care to Protect Tenants From Foreseeable Criminal Acts Committed by Third Parties in the Common Areas of an Apartment Building, 16 VILL. L. REV. 779, 780-82 (1971). For cases imposing a duty of protection upon landlords, see infra notes 77-79.

72. 38 N.J. 578,186 A.2d 291 (1962).

73. Id. at $588-89,186 \mathrm{~A} .2 \mathrm{~d}$ at 296 .

74. Id. at $589,186 \mathrm{~A} .2 \mathrm{~d}$ at 297.

75. Id. at 591,186 A.2d at 297-98. Of course the Goldberg decision attracted a good deal of criticism. See Note, Tort Doctrines and Risk Bearing Goldberg v. Housing Authority of Newark, 18 RUTGERS L. REV. 161 (1963); Note, Landowner Owes Invitee No Duty to Provide Police Protection Against Criminal Attack, 63 ColUM. L. REV. 766 (1963); Note, Negligence-Duty of Care-Municipal Housing Authority Has No Duty to Invitees to Provide Police Protection at Housing Projects, 77 HARv. L. Rev. 563 (1964).

76. 38 N.J. at $583,186 \mathrm{~A} .2 \mathrm{~d}$ at 293 . The Goldberg decision did recognize a duty on the part of the landlord to keep common areas in his control in a "reasonably safe condition," id. at 587, $186 \mathrm{~A} .2 \mathrm{~d}$ at 296 , and also suggested that a landlord could be required to take further action if his conduct in any way aided or invited criminal activity. Id. at 587, 186 A.2d at 587-88.

77. See, e.g., Kline v. 1500 Massachusetts Ave. Apartment Corp., 439 F.2d 477 (D.C. Cir. 1970); O'Hara v. Western Seven Trees Corp., 75 Cal. App. 3d 798, 142 Cal. Rptr. 487 (1977); Braitman v. Overlook Terrace Corp., 68 N.J. 368, 346 A.2d 76 (1975); Nallan v. Helmsley-Spear, Inc., 50 N.Y.2d 507, 407 
eral foreseeability of crime. Special notice of a threat has been required. ${ }^{78}$ Insofar as the Samson court found that the presence of ex-patients represented a unique, foreseeable danger, and that the landlord had notice of their presence, the imposition of liability for failure to take reasonable steps to remedy the danger does not constitute a broad expansion of landlord liability. ${ }^{79}$

N.E.2d 451 (1980). Cf. Duarte v. State, 84 Cal. App. 3d 729, 148 Cal. Rptr. 804 (1978), affd on reh., 88 Cal. App. 3d 473, 151 Cal. Rptr. 727 (1979).

78. See Kline v. 1500 Massachusetts Ave. Apartment Corp., 439 F.2d 477 (D.C. Cir. 1970) (repeated criminal acts); O'Hara v. Western Seven Trees Corp., 75 Cal. App. 3d 798, 142 Cal. Rptr. 487 (1977) (repeated criminal activity). Cf. Totten v. More Oakland Residential Housing, Inc., 63 Cal. App. 3d 538, 134 Cal. Rptr. 29 (1976) (unexpected assault); Cornpropst v. Sloan, 528 S.W.2d 188 (Tenn. 1975) (absence of notice).

It is not always clear whether a foreseeable risk creates the duty of protection or whether, instead, the scope of a preexisting duty of care is limited to protection against foreseeable risks. See Kline v. 1500 Massachusetts Ave. Apartment Corp. for the suggestion that the duty of the landlord is limited to protection against foreseeable risks but that other considerations besides foreseeability support imposition of a duty of care upon the landlord. 439 F.2d at 480-83. See Braitman v. Overlook Terrace Corp., 132 N.J. Super. 51, 55, 332 A.2d 212, 247 (1974), affd, 68 N.J. 368, 346 A.2d 76 (1975), and Scott v. Watson, 278 Md. 160, 167-70, 359 A.2d 548, 552-54 (1976), for the suggestion that foreseeability of harm creates the duty of care.

There has been criticism of a tendency on the part of the courts to confuse the existence of a duty of due care with the scope of that duty. Note, Landlord-Tenant, supra note 69, at 700-01. Foreseeability of harm has been urged as relevant to the latter inquiry, but not to the former. See View from Mass. Ave., supra note 71, at 1178; Comment, The Landlord's Emerging Responsibility For Tenant Security, 71 Colum. L. REv. 275, 277 (1971).

The Samson court did decide the duty issue separately from the foreseeability question. See $393 \mathrm{Mich}$ at 406,224 N.W.2d at 849 . The relationship of landlord to tenant can certainly be viewed as one that justifies imposition of a duty of reasonable care under the usual standards. See Kline v. Massachusetts Ave. Apartment Corp., supra; Note, Landlord-Tenant, supra note 69, at 702. Cf. 2 F. HAR PER \& F. JAMES, The Law OF TORTS $\S 18.6$, at 1052 (1956) W. PrOSSER, supra note 44, at 339. Either approach to the duty issue places great emphasis ultimately on whether the risk of harm was foreseeable.

Foreseeability is sometimes utilized, instead of either of these approaches, in ascertaining whether the negligence of the landlord constituted the proximate cause of the harm. Of course plaintiff must always prove causation in fact, that is, a causal connection between the injury sustained and the landlord's act or omission. See, e.g., McCappin v. Park Capital Corp., 42 N.J. Super. 169, 126 A.2d 51 (App. Div. 1956); Knapp v. Wilson, 535 S.W.2d 369 (Tex. Ct. App. 1976). The issue of proximate cause in a landlord-tenant case is likely to be whether the intervention of a third party was to be reasonably expected based upon the act or omission of the landlord. Thus, in Braitman v. Overlook Terrace Corp., 68 N.J. 368, 346 A.2d 76 (1975), the court concluded that the failure to repair an inadequate lock, "in light of the prior break-ins in the vicinity of defendant's building," id. at $382,346 \mathrm{~A} .2 \mathrm{~d}$ at 84 , represented the proximate cause of a resulting theft. Although the decision referred to an "enhanced risk," id., associated with the defective lock in place, the statement of the basis of recovery, "fail[ure] to supply adequate locks . . . after suitable notice of the defect," id., demonstrates that no affirmative action by the landlord was necessary for recovery. See also Warner v. Arnold, 133 Ga. App. 174, 210 S.E.2d 350 (1974).

79. Insofar as the landlord-tenant cases may continue to require some special knowledge or affirmative act before a duty to provide adequate security will be imposed, of. The 7735 Hollywood Boulevard Venture v. Superior Court, 116 Cal. App. 3d 901, 172 Cal. Rptr. 528, 529 (1981), such affirmative conduct would presumably be found in the decision of the landlord in Samson to bring foreseeably dangerous persons into the building.

There are some troublesome elements of causation in the supreme court opinion in Samson that are unrelated to the determination that ex-patients are foreseeably dangerous. For example, the court considered the failure of the landlord to inquire about the nature of the treatment at the Center to constitute a ground of recovery, without considering what the landlord would have learned as a result of the inquiry. 393 Mich. at 408,224 N.W.2d at 850 . Without proof of what could have been learned as a result of an inquiry, however, it is difficult to understand the causal connection between the alleged negligence, the failure to inquire, and the attack. This ground of liability assumes that what would have been learned at least would have tended to cause the landlord to take precautions. See Commercial Landlord, supra note 4, at 1489-90. Another element of causation that is missing in Samson concerns the proposal by the court that a reasonable landlord might have kept the Center on the first floor as a precaution. Id. at 411,224 N.W.2d at 851. Since Butzin entered the elevator for the attack on a different floor from the one on which the 
The landlord-tenant cases, however, do not provide a basis for defining the presence of ex-patients as a foreseeably dangerous condition. In order for the harm to be foreseeable, these cases require that the likelihood of criminal attack be more than a possibility. ${ }^{80}$ Their recurrent theme is that a similar incident, ${ }^{81}$ usually more than one, ${ }^{82}$ probably in the building, ${ }^{83}$ is necessary before a criminal act by a third party will be deemed foreseeable. These conditions were not met in Samson ${ }^{84}$ No prior incidents had occurred in the building. Butzin himself had been involved in one prior incident, but it had occurred such a long time before the attack in question and under such different circumstances, ${ }^{85}$ that the landlordtenant foreseeability standard does not appear to have been satisfied.

The justification for determining that ex-patients are foreseeably dangerous lies outside the landlord-tenant context of the Samson decision. That justification, which is not obvious from the opinion itself, is part of a larger tort tradition that defines dangerous persons and groups. This tradition and the place of the Samson decision in it represent an application of Professor George Fletcher's paradigm of reciprocity.

\section{The Paradigm of Reciprocity}

Professor Fletcher has suggested that liability in tort may be examined from two very different perspectives. ${ }^{86}$ One paradigm, which Fletcher refers to as the paradigm of reasonableness, ${ }^{87}$ imposes liability based upon a "utilitarian

Center was located, it is difficult to see how such a move would have tended to prevent the assault. Id. at 398,224 N.W.2d at 845.

80. See, e.g., Martin v. Usher, 55 Ill. App. 3d 409, 371 N.E.2d 69 (1977). Kline v. 1500 Massachusetts Ave. Apartment Corp., 439 F.2d 477 (D.C. Cir. 1970) suggests a foreseeability standard of "probable and predictable" risk of harm. Id. at 483.

81. Cf. Totten v. More Oakland Residential Housing, Inc., 63 Cal. App. 3d 538, 134 Cal. Rptr. 29 (1976).

82. See, e.g., O'Hara v. Western Seven Trees Corp., 75 Cal. App. 3d 798, 142 Cal. Rptr. 487 (1977); Pippin v. Chicago Housing Auth., 58 Ill. App. 3d 1092, 374 N.E.2d 1055 (1978), affd, 78 Ill. 2d 204, 399 N.E.2d 596 (1979).

83. See Scott v. Watson, 278 Md. 160, 169-70, 359 A.2d 548, 554 (1976). Cf. The 7735 Hollywood Boulevard Venture v. Superior Court, 116 Cal. App. 3d 901, 172 Cal. Rptr. 528, 529 (1981) (complaint that failed to state a cause of action was silent, inter alia, as to whether "any crime ha[d] previously occurred on these particular premises").

84. At least one observer has noted Samson's expansion of foreseeability of harm from the Kline standard of "probable and predictable" harm to the "possibility" that an ex-patient will commit a criminal act. Commercial Landlord, supra note 4, at 1489.

85. The previous attack had occurred three years before the attack on Samson. 303 Mich. at 411, 224 N.W.2d at 851 (Levin, J., dissenting). Butzin was approximately thirteen at that time. For two years prior to the attack in Samson, Butzin had been receiving treatment at the Center, and apparently had been responding adequately. Id. at 412,224 N.W.2d at 851 (Levin, J., dissenting).

86. Fletcher, Faimess and Utility in Tort Theory, 85 HARv. L. REV. 537 (1972).

Professor Fletcher's paradigms are not the only attempt to contrast legal decisionmaking based on a quasi-scientific approach with that of a non-legal community orientation. See B. ACKERMAN, PRIVATE PROPERTY AND THE CONSTITUTION (1977). The Fletcher paradigm of reciprocity is useful for understanding tort cases defining dangerous persons and groups because, in addition to the fact that it is set in the tort field and thus is readily applied to dangerous persons cases, see Comment, Psychotherapists' Liability For the Release of Mentally IIl Offenders: A Proposed Expansion of the Theory of Strict Liability, 126 U. PA. L. REV. 204, 230-31 (1977), the definition of a risk as reciprocal or nonreciprocal has the same all-or-nothing flavor that Samson and other tort cases have in defining certain persons and groups as either foreseeably dangerous or not. See generally text accompanying notes 40-43 supra, notes 109-160 infra.

87. Fletcher, supra note 86 , at $556-64$. 
calculus." 88 If the risk yields a net social utility (benefit), the victim is not entitled to recover from the risk creator; if the risk yields a net social disutility (cost), the victim is entitled to recover." 89 An apparently similar calculus is suggested by Professor Prosser as the motivation behind the rule that criminal acts generally are not deemed foreseeable because "the burden of taking continual precautions against [criminal acts] exceeds the apparent risk."90

At first glance, the Samson decision appears to be a straightforward application of the paradigm of reasonableness. The opinion seems to be viewing ex-patients as a demonstrably dangerous group that requires extraordinary security precautions. ${ }^{91}$ If Samson represents the paradigm of reasonableness, however, the opinion is plainly wrong, or at least incomplete. The tenant-plaintiff introduced no evidence that the risk of harm from ex-patients as a group or from individuals who, like Butzin, have a history of at least one violent act, is so great that precautions that are not cost-effective in the case of tenants generally are justified in the case of ex-patients. The court acknowledged that the risk of harm from ex-patients is not very great. ${ }^{92}$ In fact, it would be difficult to prove empirically that ex-patients as a group present an extraordinary risk of harm. ${ }^{93}$

While it is possible to view Samson as simply a careless application of utilitarianism, several elements of the case suggest that a wholly different and well established approach to liability was utilized in the case. Professor Fletcher's alternative approach to tort liability, the paradigm of reciprocity, ${ }^{94}$ holds the defendant liable when the defendant has imposed an unexcused, nonreciprocal risk upon the plaintiff.95 A nonreciprocal risk is one "greater in degree and different in order" from any risk imposed by the victim upon the defendant. ${ }^{96} \mathrm{~A}$ nonreciprocal risk may be quite small and remain compensable in an instance in

88. Id. at 563 n.95.

89. Id. at 542 .

90. See W. Prosser, supra note 44 , at 174 . Cf. id. at 148 ("[T] dangerous machinery, so long as the benefits outweigh the risk. . .").

Many tort theorists maintain that the goal of tort law ought to be to impose an obligation of protection whenever the cost of that burden is outweighed by the discounted benefit to be derived by the protected class. See, e.g., id. at 172 :

The duty to take precautions against the negligence of others thus becomes merely a matter of the customary process of multiplying the probability that such negligence will occur by the magnitude of the harm likely to result if it does, and weighing the result against the burden upon the defendant of exercising such care.

See also id. at 174 (same rule for determining whether taking precautions against an intentional tort should be required). This standard is often said to be based upon Judge Learned Hand's formulations in United States v. Carroll Towing Co., 159 F.2d 169 (2d Cir. 1947), and Conway v. O'Brien, 111 F.2d 611 (2d Cir. 1940). See Posner, A Theory of Negligence, 1 J. Legal STud. 29, 32 (1972). Of course this language is that of an economic analysis of law - that is, the logic of wealth maximization. See id. at 32-33 $\mathrm{n} .10$. This perspective need not lead to an endorsement of rules of negligence. See Calabresi \& Hirschoff, Toward $A$ Test for Strict Liability in Torts, 81 YALE L.J. 1055 (1972).

91. The court even spoke of balancing the probability of harm against its potential magnitude, presumably to identify the benefit of precautions to the protected class. See 393 Mich. at 406-07, 224 N.W.2d at 849 .

92. Id. at 406,224 N.W.2d at 849 .

93. See supra text accompanying notes 12-17.

94. Fletcher, supra note 86 , at 543-51.

95. Id. at 547.

96. Id. at 542 . 
which the small risk is still greater than any risk imposed upon the risk creator, ${ }^{97}$ and the risk is "different from the prevailing risks in the community."98 Whether the risk is different is tested by discovering whether the class of victims or potential victims regards the risk at issue as "a tolerable risk entailed by their way of life."99

In Fletcher's paradigm of reciprocity, the goal of the legal decisionmaker is to replicate the judgment that the community would make about the acceptability of certain risks and the unacceptability of abnormal or inappropriate risks. ${ }^{100}$ This helps to explain several puzzling aspects of the Samson opinion.

First, the supreme court was almost cavalier in its rejection of the landlord's argument that the ex-patients in his building were not foreseeably dangerous because no assaults by a patient at the Center had occurred during a period of over nine years. ${ }^{101}$ Such proof would have been critical if the plaintiff had been required to construct a rigorous cost/benefit analysis to justify increased precautions. ${ }^{102}$ On the other hand, from the point of view of the paradigm of reciprocity, the rejection of such an argument is understandable.

Essentially, the paradigm of reciprocity means that a community defines nonreciprocal risks. In order for a defendant's risk to be considered nonreciprocal, it must be not only greater than that presented by the plaintiff, but also of a different order. The risk that ordinary citizens will assault one another is reciprocal. That is, it is one of the background risks "we all impose reciprocally on each other."103 Thus, ordinarily a party would not be liable for exposing the plaintiff to a person who assaults him. ${ }^{104}$ In order for a risk of assault to be considered nonreciprocal, the risk with respect to the class in question must be considered different from that posed by the rest of the community. In this case if all that is necessary for a finding that ex-patients are dangerous is that the community considers the status of ex-patients to be abnormal, there is no reason to try to prove, or disprove, empirical assertions about the degree of the danger. ${ }^{105}$

Second, the notice given the landlord of the ex-patients' presence, which was considered a critical factor by the Samson court, gave the landlord no information except that the community, represented by average persons, considered ex-patients

97. The size of the risk is irrelevant in either direction. Id. at 548 .

98. Id. at 545 .

99. Id.

100. The entire community is the reference when the risk is one, as in Samson, to which the entire community is exposed, as opposed to judgments of offsetting risks in limited communities when two persons engage in a specific activity. See id. at 549.

101. 393 Mich. at $406-07,224$ N.W.2d at 849 .

102. It is no answer to point out, as does the supreme court in Samson, that even a small chance that a harm will occur may justify the burden of precaution if the harm is sufficiently great. See id. at 406-07, 224 N.W.2d at 849 . The economic theorists are proposing that the chance be multiplied by the magnitude of the harm. The question is not whether the chance is great or small that the harm will occur, but is rather "how great" or "how small."

103. Fletcher, supra note 86 , at 543 .

104. Cf. id. at 547-48.

105. There is still the requirement that the risk the defendant poses to the plaintiff must exceed the reverse risk. Id. at 548 . But this means only that ex-patients must be characterized as somewhat more dangerous than the average person. The community then decides whether risks posed by ex-patients are "different in order," id. at 542 , from those posed by the rest of us. 
an abnormal group, a group to be feared. ${ }^{106}$ The importance of such notice suggests that community judgment is at issue in Samson. Finally, even with no proof of dangerousness, the issue was considered one for the jury. This emphasis upon the jury is consistent with reciprocity because a jury is a court's best reflection of community judgment. ${ }^{107}$

The usefulness of the paradigm of reciprocity in accounting for important aspects of the Samson decision suggests that the paradigm, or a related, unarticulated approach, lies behind the determination that ex-patients as a group are foreseeably dangerous. This observation can be confirmed by examining a larger set of tort cases, of which Samson is characteristic, that define persons and groups as foreseeably dangerous in a manner consistent with the paradigm of reciprocity. The Samson court's conclusion that ex-patients are a foreseeably dangerous group, a conclusion reached without requiring empirical evidence and in the face of substantial empirical doubt, is not a radical departure from tort precedent. The dangerous persons and groups cases illustrate both the established place of the Samson decision in tort law and the importance of reciprocity in evaluating the area of dangerousness generally and the Samson result in particular.

\section{Dangerous Persons and Groups}

The supreme court opinion in Samson did not discuss the basis for finding that ex-patients are foreseeably dangerous. The court of appeals' decision also did not state expressly why ex-patients may be considered foreseeably dangerous. The court of appeals stated that it was "common knowledge" that "occasional[ly]" expatients assault others. ${ }^{108}$ The community-judgment rationale suggested by that description is reinforced by the court's choice of authority for its imposition of liability upon the landlord.

In its general discussion of the relationship between foreseeability and negligence, the court of appeals' majority pointed principally to two cases: Hersh $v$. Kentfield Builders, Inc. ${ }^{109}$ involving the liability of the employer who hires or retains a foreseeably dangerous person, and May $v$. Goulding, ${ }^{110}$ involving the liability of one who has taken control over a foreseeably dangerous person, but who fails to prevent the dangerous person from committing tortious or criminal acts. ${ }^{11}$ These

106. 393 Mich. at 404-05, 224 N.W.2d at 848. Complaints were not made about any acts or threats. Nor is there any indication that the ex-patients who engendered this unease ever did pose a threat of harm. It comes as no surprise that the community is made uneasy by ex-patients. See supra note 12 . Cf. O'Connor v. Donaldson, 422 U.S. 563, 575 (1975) (mentally ill may not be incarcerated to avoid public embarrassment). What notice does that fact give to the landlord beyond the existence of such community unease? On the importance of notice in the Samson decision, see supra note 38 and accompanying text.

107. Cf. Hersh v. Kentfield Builders, Inc., 385 Mich. 410, 415, 189 N.W.2d 286, 287 (1971) (jury is "conscience of the community").

108. 44 Mich. App. at 663-64, 205 N.W.2d at 836.

109. 385 Mich. 410, 189 N.W.2d 286 (1971).

110. 365 Mich. 143, 111 N.W.2d 862 (1961).

111. The court of appeals also referred to the "high crime district" in Johnston v. Harris, 387 Mich. 569,198 N.W.2d 409 (1972), in concluding that the risk in Samson was foreseeable, 44 Mich. App. at 668, 205 N.W.2d at 838. As explained supra at text accompanying notes 80-85, the landlord cases are not persuasive authority for a finding that ex-patients are dangerous. 
cases and others like them, provide a tort law context in which the decision to consider ex-patients foreseeably dangerous seems almost inevitable.

In Hersh, the Michigan Supreme Court upheld a jury verdict against an employer for failing to discover an employee's propensity for violence. The alleged negligence consisted of hiring or retaining the employee, who later attacked a salesman visiting the employer." 12 At trial, plaintiff proved that the employee had been convicted of manslaughter ten years before the attack, that he had at some point been convicted of carrying a concealed weapon, that he had been drunk occasionally on the job, and that "at times he had been belligerent."113 The trial judge charged the jury that to find negligent hiring the jury would have to find facts "which would reasonably indicate that the employee . . had a violent or vicious nature which was likely to result in injury to someone" and that the employer knew or should have known of such facts. ${ }^{114}$ It does not appear that plaintiff attempted to introduce evidence to show that the employee's violence had been probable and predictable, statistically or clinically. Such a showing probably would have been impossible given the remoteness of the one prior act of violence. ${ }^{115}$ In Hersh, a single, remote act of violence, together with occasional intoxication, intermittent belligerence, and a conviction for carrying a concealed weapon, were sufficient to sustain a jury finding that an individual has "vicious propensities"116 and to hold the employer liable for hiring such a person. "17

In May, the supreme court affirmed a denial of a directed verdict ${ }^{118}$ in the course of reversing the jury verdict because of certain unrelated interrogatories submitted to the jury. ${ }^{119}$ The alleged negligence consisted of the parents' gift of a gun to their fifteen-year-old son, who had been on temporary leave from a state mental hospital. The son had been committed four months earlier after a long history of assaultive behavior and an abnormal mania for guns. ${ }^{120}$ It may be, as

112. 385 Mich. at 412, 189 N.W.2d at 287. Plaintiff also alleged negligence in failing to discover the employee's viciousness, id., but this theory presupposed that hiring the employee with such knowledge would represent negligence.

113. 19 Mich. App. 43, 45, 172 N.W.2d 56, 57 (1969), rev'd., 385 Mich. 410, 189 N.W.2d 286 (1971).

114. 385 Mich. at 415,189 N.W.2d at 289.

115. While it may be that frequent violent acts will lead to professional prediction of future violence one incident will not necessarily do so. Cf. F. Neuman, supra note 8, at 68 ("The more frequent and vicious someone's past violent acts, the more likely he is to be violent again. Often adults who have committed crimes of violence give a long history of other similar acts, dating back to their childhood."). In any' event, the 10 years that had passed since the only other act of violence proved at trial would greatly undermine the predictive value of the violence. Cf. Pfohl, supra note 13, at 84 .

116. 385 Mich. at 415,189 N.W.2d at 289.

117. Hutchinson, the assailant, was subsequently committed to a state hospital for the criminally insane, id. at 412,189 N.W.2d at 287 , so perhaps the jury was right about his tendencies. Nevertheless, aside from the criminal record, there was nothing to suggest a tendency to violence before the act. The predictive value of the criminal act was certainly suspect. The supreme court relied upon the jury not because of its supposed insight into the likelihood of harm, but because the jury is the "conscience of the community." Id. at 415,189 N.W.2d at 287 . Hutchinson's violence was not "probable and predictable" except in the eyes of the jury. In terms of fairness, why should a court assume that a jury will treat fairly the interests of an ex-convict and the person who hired him, as opposed to the interest of one innocent, injured kitchen cabinet salesman?

118. 365 Mich. at $146-47,111$ N.W.2d at 863-64.

119. Id. at 147,111 N.W.2d at 865 .

120. Id. at $146-47$ n.2, 111 N.W.2d at $863-64$ n.2. The son shot the plaintiff, a policeman, after a robbery. Id. at 146,111 N.W.2d at 863 . 
urged by Judge Danhof in dissent in the court of appeals in Samson, that permitting any fifteen-year-old to have unsupervised access to firearms is negligent. ${ }^{121}$ But the "general rule" cited in May as underlying liability requires that the person who caused the harm be a "dangerous person."122

Like Hersh , ${ }^{123}$ May does not represent an empirical standard of foreseeable dangerousness. As the dissent pointed out, the doctors who released the boy apparently did not consider that an act of violence was predictable or probable. ${ }^{124}$ Plaintiff did not attempt to show that the risk of harm from the son was greater than that from the population as a whole, nor that professionals more competent than those who made the release decision would have considered an act of violence to be likely. ${ }^{125}$

Hersh and May, both in result and in methods of proof, fit comfortably within tort law precedents holding third parties liable for the torts of foreseeably dangerous persons. In the circumstances of Hersh, there has long been a cause of action against an employer who hires a foreseeably dangerous person who is likely to come into contact with the public. ${ }^{126}$ A single prior act of violence is not necessarily sufficient to render an employee foreseeably dangerous. ${ }^{127}$ On the other hand, in the realm of violence or criminal actions, an employer may be obliged to

121. 44 Mich. App. at $675-76,205$ N.W.2d at 842 (Danhof, J., dissenting)

122. 365 Mich. at 144,111 N.W.2d at 862-63.

123. See supra note 117 .

124. 365 Mich. at $152-54,111$ N.W.2d at 865-66 (Souris, J., dissenting). (The dissent actually was written by Justice Smith, but was adopted by Justice Souris. Justice Smith left the Michigan Supreme Court before the court decided May.)

125. At no point did the supreme court suggest that the professional judgment to release had been negligent. It may be that such a showing could have been made in May, unlike Hersh.

126. See generally Note, Torts-Master and Servant-Negligent Hiring-Employer Owes a Duty to the General Public to Use Reasonable Care in Hiring and Retaining Employees: Evans v. Morsell, 284 Md. 160, 395 A.2d 148 (1978), 9 U. Balt. L. REV. 435 (1980) [hereinafter cited as Evans Note]; Note, Negligent Hining and Negligent Entrustment: The Case Against Exclusion, 52 OR. L. REV. 296 (1973); Comment, The Responsibility of Employers For the Actions of Their Employees: The Negligent Hiring Theory of Liability, 53 CHI.-KENT L. REV. 717 (1976); [hereinafter cited as Negligent Hiring]; Rose, Liability for an Employee's Assaults, 40 MOD. L. REV. 420 (1977). This cause of action often represents an expansion of the co-employee rule. See, e.g., Evans v. Morsell, 284 Md. 160, 164-65, 395 A.2d 480, 483 (1978).

The theory of recovery may be denominated negligent hiring, negligent promotion, negligent entrustment or negligent failure to control. Negligent Hining, supra at 719. All such theories raise the same type of issues of foreseeable dangerousness on the part of the employee. See Abraham v. S.E. Onorato Garages, 50 Hawaii 628, 446 P.2d 821 (1968). These theories are not the same as a cause of action based on respondeat superior, which involves vicarious liability rather than negligence. See Evans Note, supra at 438-39.

These cases raise some issues that are unrelated to the question of which persons are foreseeably dangerous. For example, such cases sometimes turn on the issue of how detailed an inquiry should have been made when the employer has not learned of facts that show the employee to be dangerous. See, e.g., Evans Note, supra; Kendall v. Gore Properties, 236 F.2d 673 (D.C. Cir. 1956). Cf. Torno v. Yormark, 398 F. Supp. 1159 (D.N.J. 1975). Such cases may also turn on or whether the crime was committed in a way that was foreseeable, even if the employee could be said to be dangerous generally. See Argonne Apartment House Co. v. Garrison, 42 F.2d 605 (D.C. Cir. 1930) (history of intoxication does not render theft foreseeable) (dictum); F\&T Co. v. Woods, 92 N.M. 697, 594 P.2d 745 (1979) (hiring and retention not a proximate cause of injury, though dangerousness sufficiently shown to raise an issue of fact for jury). Cf. McCrink v. City of New York, 296 N.Y. 99, 71 N.E.2d 419 (1947) (uncontrolled drinking creates a jury issue of negligent retention where employment required access to firearms).

127. See R.J. Reynolds Tobacco Co. v. Newby, 145 F.2d 768, 771 (9th Cir. 1944). Cf. Abraham v. S.E. Onorato Garages, 50 Hawaii 628, 446 P.2d 821 (1968). 
foresee danger from one prior incident. ${ }^{128}$ In these cases, the plaintiff is not required to produce statistical evidence or professional opinion that would tend to show the person in question was in fact probably or predictably dangerous.

The cases of assuming control ${ }^{129}$ over a foreseeably dangerous person, of which May is an example, also represent support for a finding that someone like Butzin, or ex-patients generally, are foreseeably dangerous for purposes of holding a third party liable for intentional torts. Persons who take charge of third parties with knowledge of the third party's dangerous tendencies will be held liable for a failure to exercise reasonable care to protect others from the potential danger. ${ }^{130}$ Such cases include negligent release of confined dangerous persons, ${ }^{131}$ negligent supervision, ${ }^{132}$ negligent placement, ${ }^{133}$ and escape. ${ }^{134}$ Foreseeability ${ }^{135}$ is usually estab-

128. Mallory v. O'Neil, 69 So. 2d 313 (Fla. 1954) (prior charge of attempted murder forecloses dismissal of cause of action for negligent retention or hiring based on later shooting); Freeman v. Bell, 366 So. 2d 197, (La. App. 1978), cert. denied, 369 So. 2d 151 (La. 1979) (one shooting plus a threatened shooting renders employee foreseeably dangerous in context of later shooting); La Lone v. Smith, 39 Wash. 2d 167, 234 P.2d 893 (1951) (one prior assault plus periods of drunkeness, a quarrelsome nature, and violent temper may establish a vicious propensity to assault). Cf. Svacek v. Shelley, 359 P.2d 127 (Alaska 1961) (acts of violence render issue of dangerous propensities of employee an issue of fact for jury); Georgia Bowling Enters., Inc. v. B.W. Robbins, 103 Ga. App. 286, 119 S.E.2d 52 (1961) (prior assualts of children by party renders violent conduct foreseeable); Hall v. Smathers, 240 N.Y. 486, 148 N.E. 654 (1925) (prior acts of assault and rowdiness may establish vicious propensities). In the area of nonviolent criminal activity, see Hipp v. Hospital Auth. of City of Marietta, 104 Ga. App. 174, 121 S.E.2d 273 (1961) (prior record as a "peeping tom" may establish a propensity to molest children and creates a jury question as to duty of employer to inquire into background); Stevens v. Lunkard, 31 A.D.2d 602, 297 N.Y.S.2d 686 (1968), affd, 25 N.Y.2d 640, 254 N.E.2d 339, 306 N.Y.S.2d 257 (1969) (one prior act of sodomy may render employee foreseeably dangerous to children but no duty to make exhaustive inquiry).

129. Of course the employer-employee cases are predicated on the ability of the employer to prevent the harm to the plaintiff, and thus in a sense to control the employee. Cf. RESTATEMENT (SECOND) OF TORTS $\S 317$ comment e (1965) (negligent retention arises out of the obligation of employer to control employee). Nevertheless, the emphasis in the employment cases is on selection and retention rather than on negligence in supervision. See, e.g., F\&T Co. v. Woods, 92 N.M. 697, 594 P.2d 745 (1979). Cf. Evans Note, supra note 126, at 437 (not including negligent supervision as a potential cause of action). The control cases, on the other hand, impose an obligation upon third parties to protect others by increased interaction with the dangerous person, rather than by less. See text accompanying notes 129-37.

130. See RESTATEMENT (SECOND) OF TORTS $\$ 319$ (1965).

131. See Grimm v. Arizona Bd. of Pardons and Paroles, 115 Ariz. 260, 564 P.2d 1227 (1971).

132. See Gibson v. United States, 457 F.2d 1391 (3rd Cir. 1971).

133. See Knight v. State, 99 Mich. App. 226, 297 N.W.2d 889 (1980).

In negligent placement cases, a duty to warn, based on foreseeability, may be imposed. See Johnson v. State, 69 Cal.2d 782, 447 P.2d 352, 73 Cal. Rptr. 240 (1968); J.A. Meyers \& Co. v. Los Angeles County Probation Dep't, 78 Cal. App. 3d 309, 144 Cal. Rptr. 186 (1978). See also Rieser v. District of Columbia, 563 F.2d 462 (D.C. Cir. 1977), modified on reh'g en banc, 580 F.2d 647 (1978) (failure to disclose parolee's past history of violent acts, plus a failure to supervise, creates a jury question as to risk of harm to a tenant of the building in which parolee worked). An obligation to warn, which may be considered enforceable, may be assumed by an agent of the government. See Fair v. United States, 234 F.2d 288 (5th Cir. 1956).

134. See Webb v. State, 91 So. 2d 156 (La. App. 1956); State v. Silva, 86 Nev. 911,478 P.2d 591 (1971); Evangelical United Brethren Church v. State, 67 Wash. 2d 246, 407 P.2d 440 (1965).

135. Although there is no liability without foreseeability, there is some confusion about whether foreseeability defines the standard of care or establishes proximate cause. See Grimm v. Arizona Bd. of Pardons and Paroles, 115 Ariz. 260, 267, 564 P.2d 1227, 1233-34 (1977) (supervision over dangerous person creates duty to protect public, but this duty is violated only if there is "no reasonable basis" for board's parole decision); Annot., 19 AM. JuR. ProOf OF FACTs 2D 583, 599:

[I]n the absence of any evidence that a prison inmate was known to be especially dangerous, there generally can be no recovery for injuries inflicted by the confined person after release, whether on the ground that the release was not negligent or on the ground that it was not foreseeable that the person would intentionally harm a third person after release. 
lished by proof of prior acts of violence, ${ }^{136}$ but even prior threats may be sufficient. ${ }^{137}$ On the other hand, a professional determination such as a release decision will not be considered negligent despite prior violence merely because an appropriate medical authority exercised poor judgment about the danger. ${ }^{138}$

The control cases, like the employment cases, are not exercises in empiricism: neither statistical nor professional evidence of danger is required to justify imposition of liability. Although the phrase "likely to do harm," or some equivalent, may be employed to describe the dangerous person, ${ }^{139}$ the consistent absence in these cases of any evidence to show any specific likelihood negates the suggestion of any empirical standard.

Closely related to the employment cases and the control cases is a line of cases holding parties liable for criminal attacks by members of known groups. These cases illustrate the limits of foreseeability and represent a close analogy to Samson because they present a view of groups that is not generally discussed in cases about dangerous persons.

The Restatement of Torts discusses an "affirmative act" exception to the rule

The same ambiguity exists when a duty of due care is imposed upon the defendant, as by the requirements of a court order. See Semler v. Psychiatric Inst., 538 F.2d 121, 124-27 (4th Cir.), cert. denied sub. nom. Folliard v. Semler, 429 U.S. 827 (1976).

An affirmative act of negligence is often important in establishing liability by public agencies because such negligence is an exception to the general rule that failure to carry out governmental functions is not actionable by particular individuals harmed as a result. See Benway v. City of Watertown, 1 A.D.2d 465, 151 N.Y.S.2d 485 (1956). This rule can be avoided as well by proof of a special relationship between the government and the plaintiff. See, e.g., Rieser v. District of Columbia, 563 F.2d 462, 478-79 (D.C. Cir. 1977).

136. Thus injuries resulting from a car accident are not considered to have been proximately caused by negligence leading to an escape, see West Virginia v. Fidelity \& Cas. Co., 263 F. Supp. 88 (S.D.W.Va. 1967); Green v. State, 91 So. 2d 153 (La. App. 1956), whereas a shooting by an escapee with a history of violence is considered to be proximately caused by his escape. See Webb v. State, 91 So. 2d 156 (La. App. 1956).

See Grimm v. Arizona Bd. of Pardons \& Paroles, 115 Ariz. 260, 564 P.2d 1227 (1977); Rieser v. District of Columbia, 563 F.2d 462, 479-81 (D.C. Cir. 1977), mod. on reh. en banc, 580 F.2d 647 (D.C. Cir. 1978); Gibson v. United States, 457 F.2d 1391 (3d Cir. 1971). Cf. Evangelical United Brethren Church v. State, 67 Wash. 2d 246, 407 P.2d 440 (1965) (one prior burning incident does not render arson by escaped juvenile foreseeable).

137. Cf. Morgan v. County of Yuba, 230 Cal. App. 2d 938, 41 Cal. Rptr. 508 (1964) (negligence premised upon an unfulfilled promise to warn prior to release). Cf. Massengill v. Yuba County, 9 Ariz. App. 281, 451 P.2d 639, vacated, 104 Ariz. 518, 456 P.2d 376 (1969) (liability for accident based on failure to arrest drunk drivers).

138. See Grimm v. Arizona Bd. of Pardon \& Paroles, 115 Ariz. 260, 564 P.2d 1227 (1977); Carrington, Victims' Rights Litigation: A Wave of the Future?, 11 U. Rich. L. REV. 447, 460, 464 (1970) (problem of "second-guessing" correctional officials' good faith decision; "something extra" is required for finding of negligence).

In this area, as in any area of negligence by state agencies, immunity may be an issue, despite the existence of foreseeable harm. See, e.g., Pate v. Alabama Bd. of Pardons \& Paroles, 409 F. Supp. 478 (D. Ala. 1976); Reiff v. Pennsylvania, 397 F. Supp. 345 (E.D. Pa. 1975); Hernandez v. State, 11 Cal. App. 3d 895, 90 Cal. Rptr. 205 (1970); NeCasek v. City of Los Angeles, 233 Cal. App. 2d 131, 43 Cal. Rptr. 294 (1965); Loucks v. Adair, 312 So. 2d 531 (Fla. 1975); Lloyd v. Iowa, 251 N.W.2d 551, (Iowa 1977); Bobo v. City of Kenton, 186 Tenn. 515, 212 S.W.2d 363 (1948).

139. Cf. RESTATEMENT (SECOND) OF TORTs $\$ 319$ (1965): "One who takes charge of a third person whom he knows or should know to be likely to cause bodily harm to others if not controlled is under a duty to exercise reasonable care to control the third person to prevent him from doing such harm." See also infra note 161 . 
of nonliability for failure to prevent harm to others ${ }^{140}$ in an illustration ${ }^{141}$ factually similar to an actual case, Hines $v$. Garrett. ${ }^{142}$ That illustration ${ }^{143}$ indicates that a railroad may be found liable for a hobo's sexual assault upon a woman passenger who, after having fallen asleep and missed her stop, was "put off" a train near a place where hobos were camped. ${ }^{144}$ The Restatement's position apparently is that a railroad should know that hobos are "peculiarly likely"145 to attack women because "[i]t is notorious that many of these hobos are criminals, or men of rough and violent character." 146 It is no more obvious in the illustration than it is in the case $^{147}$ that there had actually been sexual attacks by any of the group. Similarly, in Lillie v. Thompson, ${ }^{148}$ the United States Supreme Court concluded that a jury question was presented when a railroad required an employee to work in an isolated part of its rail yards without any security, despite its having had reason to know that the "yards were frequented by dangerous characters."149

The judicial hostility to vagrants and other undesirables suggested by these

140. Normally parties are considered not to owe a duty to others to foresee and to prevent attacks by third parties. See Bradshaw v. Rawlings, 612 F.2d 135 (3rd Cir. 1979), cert. denied sub nom. Doylestown v. Bradshaw, 446 U.S. 909 (1980); RESTATEMENT (SECOND) OF TORTS \$ 314 (1965); There are two exceptions to this rule. First a party may be obligated to act because of a special relationship. See Bradshaw v. Rawlings, 612 F.2d 135 (3rd Cir. 1979), cert. denied sub. nom. Doylestown v. Bradshaw, 446 U.S. 909 (1980) (no duty by college to protect student from harm by other students); Mitchell v. Archibald \& Kendall, Inc., 573 F.2d 429 (7th Cir. 1978) (no duty to warn parked deliveryman); J.A. Meyers \& Co. v. Los Angeles County Probation Dep't, 78 Cal. App. 3d 309, 144 Cal. Rptr. 186 (1978) (no special relationship); Manquis v. Gordon, 580 P.2d 481 (Nev. 1978) (no duty owed by massage parlor operator); Williams v. State, 308 N.Y. 548, 127 N.E.2d 545 (1955) (no duty owed to victim of escape); RESTATEMENT (SECOND) OF TORTS $\S \S 314$ and 302B comment e. Cf. Neff v. Woodsmen of World Life Ins. Society, 87 N.M. 68, 529 P.2d 294 (Ct. App.), cert. denied, 87 N.M. 48, 529 P.2d 274 (1974); Christensen v. Epley, 36 Or. App. 535, 585 P.2d 416 (1978), affd in part and rev'd in part, 287 Or. 539, 601 P.2d 1216 (1979).

The second exception to the rule of nonliability is based upon an affirmative act of negligence that exposes a plaintiff to the risk of harm. See Hill v. Yaskin, 75 N.J. 139, 380 A.2d 1107 (1977); RESTATEMENT (SECOND) OF TORTS $§ 302 B$ comment e (1965). Cf. Scheibel v. Hillis, 531 S.W.2d 185 (Mo. 1976).

141. Restatement (SECOND) OF TORTS § 302B comment e, illustration 10 (1965). Subsection D describes the rule of liability as applying: "[w]here the actor has brought into contact or association with the other a person who the actor knows or should know to be peculiarly likely to commit intentional misconduct, under circumstances which afford a peculiar opportunity or temptation for such misconduct."

142. 131 Va. 125, 108 S.E. 690 (1921).

143. The case itself differs in some important respects from the illustration. Perhaps the most important difference is that in Hines there were independent attacks by two individuals, neither of whom was described by the court as a "hobo" from the nearby "hobo jungle." The first assailant had been a passenger on the train. His action raises serious issues of foreseeability that were not addressed by the court, or by the Restatement. Id. at 129-30, 108 S.E. at 691.

144. Restatement (SECOND) OF TORTS $§ 302 B$ comment e, illustration 10 (1965).

145. Restatement (Second) of Torts $\S 302 B$ comment e (1965).

146. Id. at illustration 10 .

147. The court in Hines stated that foreseeability is not the proper measure of liability. $131 \mathrm{Va}$. at 137, 108 S.E. at 693-94 (quoting Norfolk \& Western Ry. v. Whitehurst, 125 Va. 260, 263, 99 S.E. 568,569 (1919)). Nevertheless, the court noted that the place at issue could be found to be dangerous by virtue of its being infested by "worthless, irresponsible and questionable characters known as tramps and hoboes." 131 Va. at 138, 108 S.E. at 693-94. Whether letting the plaintiff off the train in such a place was negligence was for the jury to decide. Furthermore, the independent illegal act did not constitute an intervening cause because the carrier "ha[d] reason to anticipate the danger." Id. at 140, 108 S.E. at 698 . Foreseeability thus remains critical. Cf. 'McLeod v. Grant County School Dist. No. 128, 42 Wash. 2d 316, 255 P.2d 360 (1953) (jury question on foreseeability of acts of indecency. by 15-year-old school children).

148. 332 U.S. 459 (1947).

149. Id. at 460 . 
opinions is expressed forcefully in Neering v. Illinois Central Railroad Co. ${ }^{150}$ Neering presents the same type of circumstances as Hines and Lillie. Plaintiff was a wouldbe passenger who had complained to railroad officials about the presence of "hobos" at an isolated railroad station. ${ }^{151}$ Subsequently, plaintiff was attacked in the station's "warming room."152 After noting that the railroad company ought to have anticipated an assault, the court overturned an award of judgment notwithstanding the verdict for the defendant. ${ }^{153}$

The dangerous group, variously referred to by the court in Neering as "[t]ramps," "hoboes," "bums," "vagrants," and "other undesirable characters,"154 was considered by the court to represent a deviant portion of society:

This class recognized as hoboes or vagrants is commonly known as a class not living according to the standards of normal individuals and are offenders of good order and liable to become a menace to the public peace. The law recognizes, and it is generally understood, that where lawbreakers congregate they are dangerous to society and are likely to break other laws, and we do not see how it could reasonably be said when vagrants are permitted to congregate they will not become a menace to the public peace or that under such conditions one could not reasonably anticipate they might commit some unlawful act or become dangerous to society. It necessarily follows that, when such a condition is permitted to exist at a passenger station, reasonable and ordinary precaution must be observed for the protection of persons who are patrons of the road and using its passenger station. ${ }^{155}$

The reasoning of the court in Neering parallels that of the Michigan Supreme Court in Samson. The relationship of carrier to passenger created a duty to exercise ordinary care to keep the station reasonably safe. ${ }^{156}$ The railroad was deemed negligent because, despite warnings of the dangerous situation at the station, the railroad failed to take any precautions to protect the plaintiff. ${ }^{157}$ The criminal act of the unknown party did not represent an intervening cause because the event was a foreseeable consequence of the negligence. ${ }^{158}$ The issue of intervening cause was considered to be one for the jury. ${ }^{159}$ As in Samson, the character of the group both rendered the situation dangerous and rendered the assault foreseeable. As in Samson there had been no prior assaults at the place in question. ${ }^{160}$

The absence of any statistical standard of dangerousness ${ }^{161}$ and the absence of

150. 383 Ill. 366,50 N.E. $2 d 497$ (1943).

151. Id. at 369,50 N.E. $2 d$ at 499 .

152. Id.

153. Id. at $379-82,50$ N.E.2d at 503-04.

154. Id. at $371-72,50$ N.E. 2 d at 500 .

155. Id. at $376-77,50$ N.E.2d at 502 .

156. Id. at 374,50 N.E.2d at 501 . The Neering court did not impose a duty of exercising a high degree of care because plaintiff was not being transported at the time of the attack. Id. Cf. Hines v. Garrett, 131 Va. 125, 138, 108 S.E. 690,694 (1922) (duty of highest care imposed).

157. There are some statements in the opinion that suggest that the defendant's participation in creating the danger is relevant, 383 III. at $376-77,50$ N.E.2d at $501-02$, but a later statement of the rule required only knowledge and omission, rather than an affirmative act. Id. at 377-78, 50 N.E.2d at 503 .

158. Id. at 380-81, 50 N.E.2d at 503-04.

159. Id. at 381,50 N.E.2d at 504 ; no doubt the issue of negligence is for the jury as well. See id. at 377 , 50 N.E.2d at 502 ("some evidence" reasonable precautions were not taken). Of course there are some differences between Necring and the reasoning in Samson. For example, the court in Samson did not discuss causation at all.

160. Id. at 377,50 N.E.2d at 502. Cf. supra notes 25-26 and accompanying text.

161. The plaintiff is not required to show that the dangerous act was more probable than not, nor that the risk was one out of three, or satisfy any statistical test. The standard often utilized is that the individual 
statistical or clinical evidence ${ }^{162}$ supporting a claim of dangerousness suggests that the cases involving dangerous persons and groups are unrelated to the paradigm of reasonableness. In order to construct a utilitarian calculus that imposes liability when the cost of protection is outweighed by the benefits to be derived by the protected class, one needs to have an idea of the level of the risk. ${ }^{163}$ In most of the cases involving dangerous persons and groups the level of the risk would be pure speculation. ${ }^{164}$ The application of empirical data in negligence cases is not impossible; ${ }^{165}$ it simply is not done in the dangerous persons and groups cases.

These cases, including Samson, ${ }^{166}$ represent an application of the paradigm of reciprocity. The point of prior acts of violence or deviant background is to establish the non-average character of the dangerous person. ${ }^{167}$ Once the person is shown to be different from the rest of the community, he is no longer a part of the

or class in question is "likely to" commit the illegal act, see, e.g., Neering v. Ilinois Cent. R.R., 383 Ill. 366 , 376.77, 50 N.E.2d 497, 502 (1943), but this does not appear to mean "more likely than not" within some period of time; a court might mean widely considered more likely than are other people to commit such crimes, or it might mean both considered more likely comparatively and considered unacceptably likely, with the emphasis on acceptability. See supra notes 86-108 and accompanying text (discussion of Fletcher's paradigm of reciprocity). Cf. H. HART AND A. Honore, Causation in THE LAW 254 (1962) (courts sometimes label voluntary interventions unforeseeable "whether they are in fact or not").

162. Foreseeability simply is not treated as a statistical question. Thus if the negligence is firing a gun, harm to someone shot is foreseeable not because it happens once or twice out of every ten shots fired, but because "experience [has] taught us to anticipate harm" of this type from such an act. H. HART \& A. HONORE, supra note 161, at 233-34. This type of empirical vagueness has elicited criticism. See Recent Developments, Civil Commitment of the Mentally Ill, 87 HARV. L. REv. 1190, 1238-1245 (1974) [hereinafter cited as Civil Commitment]. It is not certain, however, that statistics are necessarily more appropriate than other judgments. In any event tort law has not embraced statistics. This does not mean that the medical profession has a clearer, statistical standard of danger in mind when rendering the same decision. Even when a standard is given that might seem specific, such as "extremely likely to do immediate harm to self or others," medical professionals experience difficulty in understanding the standard. See Pfohl, supra note 13 , at $82-88$.

163. See supra notes $90-102$ and accompanying text.

164. This is obvious in a case like Hersh v. Kentfield Builders, Inc. 385 Mich. 410, 189 N.W.2d 286 (1971). See supra note 115 and accompanying text. Insofar as the rule remains, as the court stated it to be in Hersh, that a "criminal record" itself is sufficient to render a person foreseeably dangerous, id. at 415,189 N.W.2d at 288 (quoting Bradley v. Stevens, 329 Mich. 556, 46 N.W.2d 382 (1951)), the rule is not grounded in demonstrable probability. Most ex-convicts, after all, do not commit further crimes. See Recent Developments, supra note 4, at 411 n.112; Comment, Employment of Former Criminals, 55 COR NELL L. REV. 306, 318 \& n.91 (1973). Some normal people also occasionally violate the law. See ProsSER, supra note 44, at 173-74.

165. See Zinck v. Whelan, 120 N.J. Super. 432, 294 A.2d 727 (1972). Cf. Peck, An Exercise Based Upon Empinical Data: Liability for Harm Caused by Stolen Automobiles, 1969 Wis. L. REV. 909. For a general evaluation of the uses of empiricism in predictions of future dangerousness, see Underwood, Law and the Crystal Ball: Predicting Behavior with Statistical Inference and Individualized Judgment, 88 YALE L.J. 1408 (1979).

166. See supra notes 86-108 and accompanying text (discussion of Samson and reciprocity).

167. See RESTATEMENT (SECOND) OF TORTS $§ 302 B$ comment d (1965):

Normally the actor has much less reason to anticipate intentional misconduct than he has to anticipate negligence. In the ordinary case he may reasonably proceed upon the assumption that others will not interfere in a manner intended to cause harm to anyone. This is true particularly where the intentional conduct is a crime, since under ordinary circumstances it may reasonably be assumed that no one will violate the criminal law.

See Sira v. Wabash R.R., 115 Mo. 127, 21 S.W. 905 (1893) (carrier need not take precaution in an apparently safe neighborhood). Cf. Fred Meyer, Inc. v. Temco Metal Prod. Co., 267 Or. 230, 516 P.2d 80 (1973); Irby v. St. Louis County Cab Co., 560 S.W.2d 392 (Mo. App. 1977).

There is no suggestion that foreseeable dangerousness as a category even is intended to isolate those who are imminently dangerous in fact. See RESTATEMENT (SECOND) OF TORTS § $302 B$ comment $e$ ("Ip]eculiarly likely to commit intentional misconduct"), \$ 319 comment a (1965) ("likely" to cause harm 
background risks that the community imposes on itself. ${ }^{168}$

Since under the reciprocity paradigm it is classification as nonaverage rather than the literal quality of dangerousness that permits the imposition of liability on the third party for failing to take steps to prevent the harm, empirical evidence is not relevant. Nor is it surprising that the determination of dangerousness may be based on many acts, one act, threats, or even deviance. ${ }^{169}$ The determinative issue is not statistical demonstration but is, rather, what the community as a whole deems to be outside the risk "prevailing in the community," 170 which might well be influenced by the shifting circumstances of particular cases.

The community judgment of dangerousness influences not only the type of proof that is introduced, but also the source of the ultimate decision about dangerousness - the jury. ${ }^{171}$ Under the paradigm of reciprocity, the only relevant inquiry is whether the risk is one that is prevailing in, and acceptable to, the community. The nature of that inquiry diminishes any claim of legitimacy by the court, as opposed to the jury, in rendering the dangerousness decision. It is not surprising then that the determination of dangerousness is often said to be based upon commonly held views, ${ }^{172}$ and that courts defer to the jury.

The recognition that reciprocity is widely accepted and that Samson is based upon that paradigm does not resolve the fundamental question of the justification for finding that ex-patients are foreseeably dangerous. That issue raises serious questions about the application of the principle of reciprocity to deinstitutionalization.

means that the person is a member of a class "to whom the tendency to act injuriously is normal" or that he is one who "has a peculiar tendency so to act"). Cf. supra note 162.

168. At that point, the person represents a risk "different in order" from the risk members of the community pose to him. See Fletcher, supra note 86, at 542.

169. See generally supra notes 109-60 and accompanying text. There is a minor empirical issue remaining. See supra note 105 and accompanying text.

170. Fletcher, supra note 86 , at 545 . It is a similar community judgment view of dangerousness that permitted the United States Supreme Court in Estelle v. Smith, 451 U.S. 454 (1981), to suggest that a finding of future dangerousness could be considered sufficiently reliable to support the imposition of the death penalty without introduction of expert testimony on the issue.

171. See, e.g., Rieser v. District of Columbia, 563 F.2d 462 (D.C. Cir. 1977), modified on reh'g. en banc, 580 F.2d 647 (1978); Hersh v. Kentfield Builders, Inc., 385 Mich. 410, 189 N.W.2d 286 (1971); State v. Silva, 86 Nev. 911, 478 P.2d 591 (1971). Of course this was the view of the Samson court as well. See 393 Mich. 393, 407, 224 N.W.2d 843, 849 (1975). This division of labor is consistent with tort principles generally, which consider issues of reasonableness to be primarily for the jury. See generally W. PROSSER, supra note 44 , at $205-08$.

172. See, e.g., Neering v. Illinois Cent. R. R., 383 Ill. 366, 376, 50 N.E.2d 497, 512 (1943) (hobos are "commonly known as a class not living according to the standards of normal individuals . . ."); Hersh $v$. Kentfield Builders, Inc., 385 Mich. 410, 416, 189 N.W.2d 286, 289 (1971) (jury as "conscience of the community" decides whether employment of ex-convicts is negligent); Fred Meyer Inc., v. Temco Metal Prods. Co., 267 Or. 230, 516 P.2d 80 (1973) (failure to foresee criminal activity under normal circumstances is outside the "community's conception of fault"). Cf. Wytupeck v. Camden, 25 N.J. 450, 461, 136 A.2d 887,894 (1957) ("unreasonable risk of harm" defined by "common consent"); Braitman v. Overlook Terrace Corp., 132 N.J. Super. 51, 55, 332 A.2d 212, 214 (1974), affd, 68 N.J. 368, 346 A.2d 76 ("proximate cause can be established by demonstrating that according to the common experience of mankind the resulting injury was a reasonably foreseeable consequence of the negligent act"). This approach was taken expressly by the court of appeals in Samson. See 44 Mich. App. 658, 663-64, 205 N.W.2d 833, 836 (1973) ("common knowledge" that mental patients on convalescent leave commit assaults and homicides). 


\section{E. Reciprocity and Deinstitutionalization}

At this point it should be clear that Samson does not go far beyond well-established tort precedent in imposing liability upon landlords renting to ex-patients and related institutions. There are landlord-tenant cases that support the imposition of a duty to remedy a dangerous condition on the premises. ${ }^{173}$ The cases involving dangerous persons and groups support the determination that expatients are foreseeably dangerous as a group, either because of their mental illness or because of prior violence. ${ }^{174}$ There is even support for the view that once the decision to rent is made, liability should be absolute rather than based upon negligence. ${ }^{175}$ Because Samson is well-supported, criticism of the determination that expatients are foreseeably dangerous must either attack the use of reciprocity to determine dangerousness or point to special factors in the area of deinstitutionalization that render reciprocity inappropriate.

It is beyond the scope of this paper to evaluate generally the reciprocity paradigm. Nevertheless, a charge of discrimination obviously can be leveled at a system that permits the majority, through the mechanism of a jury, to burden unpopular minorities, such as ex-convicts, vagrants, and the mentally ill, by defining the community in a way which excludes their participation. Absolute judicial deference to such community judgment in the absence of any empirical evidence of danger contrasts starkly with the nondeferential equal protection standard which the courts would apply if the community, through its legislature, burdened other discrete and insular minorities. ${ }^{176}$

Samson can be said to be wrongly decided, however, without reference to any such general criticism of reciprocity. In Samson, either the status of ex-patient, or that status plus a violent history, renders a person foreseeably dangerous. The essence of the deinstitutionalization movement, on the other hand, is that mental patients with violent histories should be released as a general rule, in the absence of professional judgment of special danger. ${ }^{177}$ Since deinstitutionalization is a leg-

173. See supra notes $57-85$ and accompanying text.

174. See supra notes 109-72 and accompanying text. Certainly the mentally ill would be considered by many to be "undesirable characters," like hobos. See supra notes 12, 106, 150-60 and accompanying text.

175. See supra notes $48,129$.

176. Cf. United States v. Carolene Prods., 304 U.S. 144, 152 n.4 (1938). Certainly the mentally ill share characteristics with other groups to whom the courts have extended protection from the actions of political majorities. See Note, Mental Illness: A Suspect Classification, 83 YaLE L.J. 1237 (1974). Widespread limitations on the access of the mentally ill to the franchise, see Note, Mental Disability and the Right to Vote, 88 YaLE L.J. 1644, 1945-47 (1979), perhaps provide the best argument for such judicial scrutiny. Cf. J. Choper, Judicial Review and the National Political Process 75-77 (1980). The judgment in Samson that ex-patients are dangerous to other tenants appears particularly vulnerable to judicial review on equal protection grounds because the judgment is rooted in "loose-fitting characterizations" about the mentally ill, the accuracy of which could not be demonstrated. See Craig v. Boren, 429 U.S. 190, 198-99 (1976). Even a limited standard of review, see Reed v. Reed, 404 U.S. 71, 75-76 (1971), would contrast with the Samson court's unthinking acceptance of stereotypes about the mentally ill. See 393 Mich. at 416 17, 224 N.W.2d at 853 (Levin, J., dissenting). Cf. 44 Mich. App. at 663-64, 205 N.W.2d at 836 ("common knowledge" that mental patients on convalescent leave commit violent acts). The reliance upon such stereotypes has been considered objectionable. See Orr v. Orr, 440 U.S. 268, 283 (1979). Such decisions by a jury would be entitled to less deference by a court than a similar determination by a democratically elected legislature. Professor Fletcher does not appear to be concerned about the possibility of community hostility against unpopular groups or activities. See Fletcher, supra note 86 , at 538-39 \& n.5.

177. Generally speaking, involuntary civil commitment requires that the person to be committed be 
islative policy, ${ }^{178}$ application of reciprocity to deinstitutionalization brings the judiciary into conflict with a legislative judgment. In determining that most expatients are dangerous the Samson court decided that a class of persons whom the legislative branch has determined should be released ${ }^{179}$ represents a risk the com-

dangerous to himself or others. See Civil Commitment, supra note 162, at 1201-07. Cf. R. ROCK, M. Jacobson \& R. Janopaul, Hospitalization and Discharge of the Mentally Ill (1980) (discharge standards). It is widely accepted that the dangerousness standard for involuntary commitment requires evidence of "a recent overt act, attempt, or threat." Brooks, supra note 7, at 18. Thus the issue of release will generally not arise unless someone has in the past engaged in behavior that would render him foreseeably dangerous under the standard of the dangerous persons and groups cases.

Large numbers of patients who might have been institutionalized in the past, and are now either released or never admitted, may be presumed to have had at least one prior episode of violence. The prevalent judicial view of proper psychiatric practice is that "institutionalization is the exception, not the rule." Johnson v. United States, 409 F. Supp. 1283, 1293 (M.D. Fla. 1976), rev'd and remanded on other grounds, 576 F.2d 615 (5th Cir. 1978). "[M]odern psychiatric practice does not require a patient to be isolated from normal human activities until every possible danger has passed. Because of the virtual impossibility of predicting dangerousness, such an approach would necessarily lead to prolonged incarceration for many patients who could become useful members of society." Id. Cf. Higging v. State, 24 A.D.2d 147, 265 N.Y.S.2d 254 (1965); Taig v. State, 19 A.D.2d 182, 241 N.Y.S.2d 495 (1963); St. George v. State, 283 A.D. 245, 127 N.Y.S.2d 147, affd., 308 N.Y. 681 , 124 N.E.2d 320 (1954); Timmons v. State, 58 Misc. 2d 696, 296 N.Y.S.2d 429 (1968); Milano v. State, 44 Misc. 2d 290, 253 N.Y.S.2d 662, 675 (1964); Schwenk v. State, 205 Misc. 407, 129 N.Y.S.2d 92 (1953), app. dism'd, 131 N.Y.S.2d 455 (App. Div.) (1954). The courts have often recognized the approval by the legislatures of such an approach to treatment of the mentally ill. See, e.g., Johnson v. United States, 409 F. Supp. 1283 (M.D. Fla. 1976); Hernandez v. State, 11 Cal. App. 3d 895, 90 Cal. Rptr. 205 (1970); Seavy v. State, 21 A.D.2d 445, 250 N.Y.S.2d 877 (1964), affd., 17 N.Y.2d 675, 269 N.Y.S.2d 455 (1966).

178. Deinstitutionalization as a program very early represented a clear policy determination by the political branches of various governments. See, e.g., the following description of the role of the federal government in 1963:

In 1963 the Government embarked on a bold new approach to improve the care and treatment of the mentally ill. This new approach involved starting a series of programs to stimulate and support an array of community services as alternatives to institutioned care, which enable mentally disabled persons to remain in or return to their communities and to be as independent and self supporting as possible. This approach has been referred to as "deinstitutionalization."

G.A.O. REPORT, supra note 4, at 1 . The role of the Federal Government in supporting deinstitutionalization in a variety of contexts has been noted. See Zoning, supra note 6, at 862-66. While deinstitutionalization has had its judicial impetus, see Shuman \& Hawkins, supra note 7, at 1183-84; Group Homes, supra note 6 , at 680-81; the standards of institutionalization and release remain in larger part a legislative prerogative once mental illness is established. See Addington v. Texas, 441 U.S. 418, 425-26 (1979).

It is not difficult to discern legislative preference for deinstitutionalization. While state authorities have resisted calls for the abolition of involuntary commitment, see Note, A New Emancipation: Toward An End to Involuntary Civil Commitments, 48 NOTRE DAME L. REV. 1334 (1973), there has been a trend in recent legislative efforts in the commitment field to support the goals of deinstitutionalization by restricting the scope of involuntary commitment to the imminently dangerous mentally ill. See Civil Commitment, supra note 162, at 1205-06. In Pennsylvania, for example, a person who has been committed must be released as soon as it no longer is a "reasonable probability" that the person will attempt to inflict "serious bodily harm on another" or that he represents a clear and present danger to himself. See Mental Health Procedures Act, as amended, 50 PA. CoNST. ANN. $\S \S 7101,7301,7304$ g(3) (Supp. 1981).

179. Michigan enacted a new Mental Health Code in August 1974. 1974 Mich. Pub. Acts 258 (Mich. Comp. LAws ANN. \$ 330.1001-2106 (1975)). See Comment, Problems of Chaplers 4, 5 and 8 of the New Michigan Mental Health Code, 1975 Der. C.L. REV. 229. The standard of commitment under this law, was inter alia, danger to others. Under the 1975 MiCH. PUB. ACTS 179, (amending MiCH. Comp. LAWs ANN. $\S 330.1401$ (1975)), the standard for commitment was that the person's behavior might result in harm to others. See Note, Michigan's Revised Mental Health Code, 9 U. Mich. J.L. REF, 620, 629 (1976). There was some ambiguity at the time Samson was decided about whether an overt act was required before the new standard would be satisfied. See id. at 629-30. The important point for our purposes is that, consistent with the goals of deinstitutionalization, the 1974 act directed that persons who had been involuntarily committed be released when they no longer met commitment standards. See Mich. Comp. LAwS ANN. 
munity considers intolerable. ${ }^{180}$

Reciprocity does not provide a justification for such judicial/legislative conflict. The fact that a representative branch of government has decided to tolerate, and even encourage, whatever risk ex-patients present is strong evidence of what the community considers a normal and appropriate risk. ${ }^{181}$ It simply is not to be expected that democratically elected legislatures will seek to expose the community to risks deemed unacceptable by the community. The legislative judgment in this regard is entitled to more weight than the decision of the jury, a less representative body. ${ }^{182}$ In fact, because of the policy of deinstitutionalization, contact between ex-patients and the rest of the community may now be so widespread ${ }^{183}$ that a future court examining deinstitutionalization may have difficulty sustaining a jury decision that such contact is "aberrant." 184

Even more important than the accuracy of the legislative judgment is the prescriptive authority of the legislature. The question of what risks are tolerable, acceptable, normal, or natural is not entirely an objective one, susceptible of measurement in time. Deinstitutionalization represents in part a legislative judgment that the presence of the mentally ill in society ought to be considered acceptable by the community, whether in fact it is yet so considered or not. ${ }^{185}$ Thus, unlike

$\S 330.1476$ (1975). Thus under the legislative policy, some persons who had been adjudged mentally ill and dangerous at some prior time would be released.

180. Another indication of the support for deinstitutionalization by the State of Michigan, if not by the legislature, is that the State of Michigan created the Saginaw Valley Consultation Center to provide out-patient care for deinstitutionalized mental patients. See 44 Mich. App. at 672, 205 N.W.2d at 840 (Danhof, J., dissenting).

Aside from public support of the general program of deinstitutionalization, the decision to release Butzin was a public decision. The decision to permit Butzin to live in the community was made by the Michigan State Department of Public Health. 44 Mich. App. at 666, 205 N.W.2d at 836. The Supreme Court did not criticize the decision to release Butzin or any of the other ex-patients at the Center; nor did the court utilize the convalescent status rationale that the court of appeals attempted to articulate. See 44 Mich. App. at 666-67, 205 N.W.2d at 837-38. The supreme court even used the word "released" in describing the general rule of dangerousness. 393 Mich. at 406,224 N.W.2d at 849 . The foreseeably dangerous group thus appears to include persons who should be released under the state's deinstitutionalization program.

181. Cf. Fletcher, supra note 86, at 545 (describing Rylands v. Fletcher, 159 Eng. Rep. 737 (1865), rev'd, 1 L.R.-Ex. 265 (1866), affd., 3 L.R.-H.L. 330 (1868), as a case that involved the imposition of an "abnormal" and "inappropriate" risk).

182. It is certainly possible to doubt the representative character of the political branches in the federal and state governments. See A. Bickel, The Least Dangerous Branch 16-20 (1962); S. Krislov, The Supreme Court and Political Freedom 20 (1968); M. Shapiro, Freedom of Speech: The. Supreme CoURT AND Judicial Review 17-25 (1966). But just as that observation does not necessarily lead to the conclusion that courts and legislatures are equally representative, of. BICKEL, supra, it also does not establish the jury's majoritarian roots. It may be that a jury can be considered "the conscience of the community," Hersh v. Kentfield Builders, Inc., 388 Mich. 410, 415, 189 N.W.2d 286, 287 (1971), when compared to a judge, but not when compared to a large group of elected representatives.

There are two problems in particular in relying upon a jury verdict for a determination of community values. First, there is no decision, except to grant money. Therefore, one can never be sure why an award was made. Sympathy for the victim, rather than any fear of ex-patients, may have been the reason for the Samson decision. Second, even if both bodies, jury and legislature, were considered to be representative in some sense, the nature of their judgments would still differ. A legislature sometimes gives reasons for its actions, and each member's decision usually is recorded. The jury's decision is in secret, and unprincipled, formally speaking. Thus unreflective prejudice may be more likely to emerge from a jury.

183. See supra note 8.

184. Fletcher, supra note 86 , at 548 .

185. In matters of defining the acceptability of certain types of risks, a legislature no doubt may 
activities that merely are "legally permissible," for which liability may be imposed, ${ }^{186}$ deinstitutionalization is itself a legislative undertaking. Through a democratically elected body, and however hesitantly, the community has chosen to impose the risks of deinstitutionalization upon itself. Samson represents unjustified judicial resistance to this decision. ${ }^{187}$

This analysis does not mean that tort law has no role to play in assessing the risks posed by deinstitutionalization. Samson represents a gross judgment that all or almost all ex-patients represent a foreseeable danger in almost any context of contact between ex-patients and anyone else. ${ }^{188}$ It is this gross judgment that conflicts with deinstitutionalization. On the other hand, deinstitutionalization does not necessarily mean that all mental patients should be released nor that all expatients should be placed in every context in the community. Such "fine-tuning" decisions permit a fairer accommodation of the interests of ex-patients and the community than does Samson liability. ${ }^{189}$ One example of such a tort tradition already exists in cases assessing the tort liability of professionals in commitment/release decisions.

\section{F. Professional Liability}

The professional liability standard provides for some financial recovery to victims, protects ex-patients from popular prejudice, and is consistent with the legislative policy of deinstitutionalization. This standard of liability is imposed by the courts on persons who must decide whether to commit, release, or recommit potentially dangerous persons: specifically, for our purposes, mentally ill persons. Since such persons usually have a history of violence, ${ }^{190}$ the Samson standard would render the professional potentially liable in most cases. ${ }^{191}$ The professional lia-

operate as an "educational body" in the same way as does a court. Cf. Rostow, The Democratic Character of Judicial Review, 66 HaRv. L. Rev. 193 (1962). Decisions such as Samson or new commitment statutes, cannot be considered static representations of community judgment. Such decisions have important effects on developing community opinion. See Levy, Judicial Review of History, and Democracy, in JUDICIAL REVIEW AND THE SUPREME CoURT 33-34 (L. Levy ed. 1967).

186. Fletcher, supro note 86 , at 545 .

187. It may be objected that this "clear" legislative policy did not provide immunity to all those who provide services to ex-patients. Cf. Recent Developments, supra note 4, at 383 . The answer to this observation is first that such widespread immunity might lead to immunity in areas unrelated to deinstitutionalization, and, second, that the legislature might well desire that the courts "fine-tune" judgments about dangerousness on a case by case basis.

188. See supre notes $32-39$ and accompanying text.

189. The idea that "fine-tuning" decisions could be considered an illustration of reciprocity may seem surprising. The paradigm is associated primarily with strict liability. See Fletcher, supra note 86, at 543-44. If one is exposed to a non-reciprocal risk, and is injured thereby, one recovers. The employment cases, see supra notes 126-28 and accompanying text, appear to impose such strict liability for hiring dangerous people. On the other hand, a case by case analysis of precautions taken, as in the control cases, supra notes 130-38 and accompanying text, should not be considered necessary for reciprocity. The apparent conflict is resolved if one distinguishes among different kinds of risks deemed "tolerable" by the community. See Fletcher, supra note 86, at 545. It may be that ex-patients in highly stressful situations are considered dangerous, for example.

190. See supra note 177 .

191. In almost every case in which an ex-patient harmed someone intentionally it could be said, plausibly, that the medical professional brought a foreseeably dangerous person into contact with the public, if dangerousness were always defined in terms of past violence. Cf. RESTATEMENT (SECOND) OF TORTS $\S 319$ (1965). 
bility standard places a limit upon such liability by not requiring these professionals to anticipate future violence in every case in which violence is possible.

Despite occasional indications that release decisions would be subject to a high degree of care, ${ }^{192}$ there has been recognition since before the advent of full deinstitutionalization that medical professionals must exercise some discretion in the decision to release. ${ }^{193}$ The general rule of liability is that in the absence of a failure to follow expected procedures ${ }^{194}$ or an obvious breach of professional conduct, ${ }^{195}$ there will not be liability for mistaken professional judgment, ${ }^{196}$ although a duty may be imposed to inform fully the party caring for the person released. ${ }^{197}$

The best-known case to utilize the professional liability standard, although not in the release context, is Tarasoff $v$. Regents of University of Califormia ${ }^{198}$ In that case the Supreme Court of California held that the failure to warn the intended victim of a patient established a cause of action against the therapist. ${ }^{199}$ The court stated that the therapist could be held liable for failure to take reasonable precautions ${ }^{200}$ when the therapist determines, or pursuant to the standards of his profession should determine, that the patient is dangerous. ${ }^{201}$ The standard of error is one of professional malpractice, rather than of mistaken judgment. ${ }^{202}$

The important difference ${ }^{203}$ between Samson and Tarasoff is that, in the latter, a

192. See, e.g., Eanes v. United States 407 F.2d 823 (4th Cir. 1969). Cf. Semler v. Psychiatric Inst., 538 F.2d 121 (4th Cir.), cert. denied, 429 U.S. 827 (1976).

193. See, e.g., St. George v. State, 283 A.D. 245, 127 N.Y.S.2d 147 (1954). Cf. Underwood v. United States, 356 F.2d 92 (5th Cir. 1966).

194. See, e.g., Hicks v. United States, 511 F.2d 407 (D.C. Cir. 1975); Williams v. United States, 450 F. Supp. 1040 (1978). But see Januszko v. State, 93 Misc. 2d 1041, 404 N.Y.S.2d 486 (1976).

195. See, e.g., Homere v. State, 48 A.D.2d 422, 370 N.Y.S.2d 246 (1975).

196. See Hicks v. United States, 511 F.2d 407 (D.C. Cir. 1975); Johnson v. United States, 409 F. Supp. 1283 (M.D. Fla. 1976), rev'd and remanded on other grounds, 576 F.2d 615 (5th Cir. 1978); Leverett v. State, 61 Ohio App. 2d 35, 399 N.E.2d 106, (1978). Cf. McDowell v. County of Alameda, 88 Cal. App. 3d 321, 151 Cal. Rptr. 779 (1978); Cameron v. State, 37 A.D.2d 46, 322 N.Y.S.2d 562 (1971).

197. See Merchants Nat'l Bank \& Trust Co. v. United States, 272 F. Supp. 409 (D.N.D. 1967). Cf. Seavy v. State, 21 App. Div. 2d 445, 250 N.Y.S.2d 877 (1964), affd, 17 N.Y.2d 675, 216 N.E.2d 613,269 N.Y.S.2d 455 (1966).

Professional liability may also be limited on the basis of remoteness of the decision from the harm. See Martinez v. California, 444 U.S. 277 (1979), reh. denied, 445 U.S. 920 (1980); Harris v. State, 48 Ohio Misc. 27, 358 N.E.2d 639 (1976); see also Bowers v. Devito, 486 F. Supp. 742 (N.D. Ill. 1980). Cf. Leverett v. State, 61 Ohio App. 2d 35, 399 N.E.2d 106, (1978).

198. 17 Cal. 3d 425, 551 P.2d 334, 131 Cal. Rptr. 14 (1976).

199. Id. at 431,551 P.2d at $340,131 \mathrm{Cal}$. Rptr. at 20

200. The court did not require warnings in all cases. A warning was merely one of the "alternatives" available to satisfy the duty to take reasonable steps to protect the victim. Id. at 439,551 P.2d at $345-46$, 131 Cal. Rptr. at 26.

201. Id. at 439,551 P.2d at $345,131 \mathrm{Cal}$. Rptr. at 25.

202. Id. at 438, 551 P.2d at 345, $131 \mathrm{Cal}$. Rptr. at 25. Aside from the standard of foreseeability of dangerousness, the contours of the Tarasoff duty are not clear. See Thompson v. County of Alameda, 27 Cal. 3d 741, $167 \mathrm{Cal}$. Rptr. 70 (1980) (no duty to warn in absence of threats against a foreseeable or readily identifiable victim); McDowell v. County of Alameda, $88 \mathrm{Cal}$. App. 3d 321, 151 Cal. Rptr. 779 (1979) (Tarasoff duty does not protect members of public generally). Cf. Leedy v. Hartnett, 510 F. Supp. 1125 (M.D. Penn. 1981); McIntosh v. Milano, 168 N.J. Super. 466, 403 A.2d 500 (1979). But see Lipari v. Sears, Roebuck \& Co., 497 F. Supp. 185, 194-95 (D. Neb. 1980).

203. The professional liability standard is more consistent with the paradigm of reasonableness than are the dangerous persons and groups cases. There appears to be, normally, a requirement of evidence from other medical professionals that the therapist should have predicted dangerousness before the therapist may be held liable. See Mavroudis v. Superior Court, 102 Cal. App. 3d 594, 605-06, 162 Cal. Rptr. 724,733 (1980). Such professional evidence might indicate that a balancing of probabilities is to be 
prior act of violence does not appear sufficient to permit a jury to find that a therapist should have predicted danger. Some additional factor beyond a violent history is required before the determination of dangerousness must be made. ${ }^{204}$ This standard of liability protects the class of ex-patients with violent histories from an unduly burdensome liability rule. Under the professional liability standard, there is no reason to suppose that the landlord in Samson would have been liable. ${ }^{205}$

Utilizing either of Professor Fletcher's paradigms, the standard of professional liability for prediction of dangerousness is a more appropriate standard of liability for harm by ex-patients than is the Samson standard. Under a utilitarian calculus, the claim has not been proved, in Samson or generally, that ex-patients as a group are so dangerous that special security precautions for ex-patients are necessary to offset the risk to potential victims. ${ }^{206}$ There may be some ex-patients for whom this is true, and some circumstances of special danger, but the professional liability standard would encourage recognition of such factors by landlords, as it does by medical professionals. In terms of reciprocity, the community may judge that despite the general acceptability of deinstitutionalization, some ex-patients in some sensitive circumstances represent unacceptable risks. While ex-patients as a group represent a background risk, an ex-patient who has threatened certain people or has been misdiagnosed or who is being placed in a particularly stressful position may be judged by the community to represent an entirely different order of risk. ${ }^{207}$

attempted. Nevertheless, professional evidence is not necessarily inconsistent with the paradigm of reciprocity. An ex-patient who has not been evaluated in accordance with professional standards might be said to represent a different order of risk than the average ex-patient.

204. Although not at issue in the case because of an actual prediction of violence, the court indicated that there was no objective factor that would automatically render the therapist liable for failing to predict dangerousness. "Within the broad range of reasonable practice and treatment in which professional opinion and judgment may differ, the therapist is free to exercise his or her own best judgment without liability; proof, aided by hindsight, that he or she judged wrongly is insufficient to establish negligence." $17 \mathrm{Cal}$. 3d at 438, 551 P.2d at 345, $131 \mathrm{Cal}$. Rptr. at 25. Since many such judgments involve persons with a record of violence, permitting a jury determination based only on a prior act of violence would contravene the court's attempt to balance professional judgments against gross errors. In Mavroudis v. Superior Court, 102 Cal. App. 3d 594, 162 Cal. Rptr. 733 (1980), the court suggested that only an actual threat could create automatic notice of danger. Id. at 594, 162 Cal. Rptr. at 733.

205. There is no information in the court of appeals or supreme court opinions that Butzin, or any other patient at the Center, had engaged in recent behavior that should have led a competent professional to predict an outburst of violent behavior. Butzin's behavior apparently had stabilized. Cf. Recent Developments, supra note 4, at $385 \mathrm{n}$.14. The landlord already knew of the mental illness and history of violence of persons treated at the Center, and could have learned nothing more. These factors, mental illness and a history of violence, do not require a prediction of dangerousness under the professional liability standard.

206. See supra notes 16-17 and accompanying text. The likely outcome of such balancing is put into even greater doubt when the cost of greater isolation of ex-patients is counted as a cost of precautions. See supra notes 44-45 and accompanying text.

207. The trend in tort cases of harm by the mentally ill is not yet clear. In cases of release, the professional liability standard is usually applied. See supra notes 194-97 and accompanying text. On the other hand, in cases of supervision of the mentally ill, or those involving lay people, a standard like that of Samson appears to be applied. In some cases, for example, the guardian or hospital staff supervising a mentally ill person will be held not liable for his actions because similar acts had not occurred before and thus were not foreseeable. See, e.g., Moon v. United States, 512 F. Supp. 140 (D. Nev. 1981); Schwartz v. United States, 226 F. Supp. 84 (D.D.C. 1964); Alva v. Cook, 49 Cal. 3d 899, 123 Cal. Rptr. 166 (1975); Sego v. Meins, 578 P.2d 1069 (Colo. App. 1978). Cf. Ajirogi v. Hawaii, 59 Hawaii 515, 583 P.2d 980 


\section{CONCLUSION}

The assertion that ex-patients are foreseeably dangerous has an uncertain empirical basis. Furthermore, such a judgment cannot be sustained by reference to community views about acceptable risks. In fact, cases adjudicating liability for the release decision, the very context in which such a judgment would assume crucial importance, do not appear to assume that ex-patients as a group are foreseeably dangerous. Against this array, how is one to account for Samson?

The answer probably lies in the vulnerable position of Carol Samson. There is, in Samson, a distinct flavor of enterprise liability ${ }^{208}$ for the benefit of the victims of deinstitutionalization. ${ }^{209}$ The legislature had created a program that harmed, predictably, a certain class of persons. ${ }^{210}$ While it may certainly be objected that

(1978); Hilscher v. State, 64 Misc. 2d 368, 314 N.Y.2d 904 (1970); May v. Triple Convalescent Centers, 19 Wash. App. 794, 578 P.2d 541 (1978). It could be argued that these cases are just like the dangerous persons and groups cases because foreseeability based upon prior acts is required. Although this standard can be utilized, as above, to limit liability, where a prior pattern does exist, the same standard could be used to impose liability. It appears, however, that in the area of the mentally ill, more of a prior pattern is required than is the case in Neering, for example, or in Samson itself. Some cases seem plainly to suggest a standard of professional liability. See Moon v. United States, 512 F. Supp. 140 (D. Nev. 1981); Schwartz v. United States, 226 F. Supp. 84 (D.D.C. 1964); see also Puckett v. Cox, 456 F.2d 233 (6th Cir. 1972). There are, on the other hand, cases imposing liability which do not require any special showing of dangerousness. See, e.g., Mathes v. Ireland, 419 N.E.2d 782 (Ind. App. 1981); May v. Goulding, 365 Mich. 143, 111 N.W.2d 862 (1961).

There is no way to specify in advance what information concerning the history of an ex-patient or concerning details of his placement in the community might render a particular ex-patient foreseeably dangerous under a professional liability standard. Under that standard, however, ex-patient status, even accompanied by the usual history of violence, would not count as a reason for a landlord to take any security precautions. Nor would these facts alone require a landlord to investigate an ex-patient, for these facts are inevitably present because of the legislative decision to promote deinstitutionalization and are the very facts that were taken into account when the decision to release was made. Liability might be imposed on the landlord, nevertheless, where other information, or knowledge of some change in an ex-patient's condition, which might render a particular ex-patient foreseeably dangerous in a particular context come to the landlord's attention. See supra text accompanying notes 188-89.

Samson liability defines ex-patients as foreseeably dangerous merely because of that status and a prior history of violence. It is this definition of foreseeable dangerousness, as opposed to a case by case judgment with regard to special information the landlord has acquired, that conflicts with the legislative policy of deinstitutionalization.

208. Enterprise liability is a loose term that describes a liability rule in which enterprises pay for all damages resulting from their enterprise. "[T]hose who reap the profit . . . should also pay the costs . . . ." D. Noel \& J. Phillips, Cases and Materials ON TORts and Related Law, 22 (1980). The application of such a rule is often limited to dangerous activities, see, e.g., Exner v. Sherman Power Constr. Co., 54 F.2d 510, 514 (2d Cir. 1931) ("when a person engages in . . . a dangerous activity, useful though it be, he becomes an insurer"), (see generally RESTATEMENT (SECOND) OF TORTs $\$ \S 519,520$ (1977)), but has been proposed in other areas on the ground that, for the sake of innocent victims, inevitable injuries ought to be distributed among persons benefitting from the activity. See Freezer, Social Justice in the Field of Torts, 11 Minn. L. Rev. 313, 323 (1926); O'Connell, Expanding No Fault, 59 VA. L. ReV. 749, 776 (1973); James, Some Reflections on the Bases of Sirict Liability, 18 LA. L. REV. 293, 296 (1958); cf. ProsseR, supra note 44, at 22-23.

209. The treatment of ex-patients as an abnormally dangerous group that justifies a special liability rule parallels the usual enterprise liability approach to abnormally dangerous activities that must compensate for all losses. Restatement (SECOND) OF TORTs $\$ \S 519,520$ (1977). The analogy is not complete because Samson liability is not formulated as a rule of absolute liability, although that difference may be of more theoretical interest than practical application. See supra note 48.

210. The majority referred obliquely to the "strong social considerations" underlying the duty of a landlord to protect tenants. 393 Mich. at 409, 224 N.W.2d at 850 . The dissent referred to the matter more fully: "There is understandable sympathy for Samson. She is the happenstance victim of a public policy which favors the release of mental patients who, in the judgment of the authorities, are ready to resume life 
landlord liability in the context of deinstitutionalization could never achieve the goals of enterprise liability, ${ }^{211}$ compensation for harm from deinstitutionalization is certainly desirable. ${ }^{212}$ As one recent call for such enterprise' liability has recognized, however, recovery under such a system ultimately must come from public funds or the program of deinstitutionalization is likely to be undermined; ${ }^{213}$ strict liability imposed on participants in the deinstitutionalizátion process simply will encourage such persons to restrict their involvement. A public victim compensation program requires legislative rather than judicial action. In the absence of such a public program, the courts should not design a private compensation system that threatens to upset the legislatively determined balance between the benefits of deinstitutionalization and its risks. ${ }^{214}$

in the community." Id. at 417,224 N.W.2d at 854 . (Levin, J., dissenting). It is important to note in the context of victim compensation the likelihood that ex-patients held liable personally may be unable to satisfy a judgment. No matter how "average" the level of violence of ex-patients is, in fact, some persons will become victims of assaults who would not be assaulted if more mentally ill persons were institutionalized. See infra note 212 .

211. Landlord liability does not spread costs. The benefits of deinstitutionalization accrue to all of society, not only because there is a general benefit from humane policy, but because any citizen might at some point require psychiatric assistance and thus benefit specifically from a policy of reduced hospitalization. Nevertheless, for reasons stated, sec supra notes 44-56 and accompanying text, the costs of Samson liability tend to fall upon landlords and immediate beneficiaries of deinstitutionalization. $C f$. Chavez v. So. Pac. Trans. Co., 413 F. Supp. 1203, 1209 (E.D. Cal. 1976) (defendant strictly liable because it both benefits from the activity and can spread costs of the activity among the public).

Nor does landlord liability encourage precautions by the proper party. The occasions of harm from deinstitutionalization do not always fall in the landlord context. Samson liability would not apply if Butzin had attacked someone on the sidewalk outside the building. Even if causation in landlord liability cases were expanded so that the landlord were liable for torts on property near his premises, see Tenant Selection, supra note 4, at 756-60, there would still come a point, perhaps quite often, at which the tort is unrelated to the premises. At such a point, only the person who released the ex-patient, or refused to commit the individual, could be identified as the party conducting the enterprise of deinstitutionalization upon which liability is to be assessed. The observation that medical professionals may be a more logical choice for liability than are landlords merely emphasizes the irony that medical professionals are held to a lesser standard. See supra notes 190-207.

212. Although ex-patients may not be particularly dangerous as a group, it is still "predictable in an aggregate sense" that some ex-patients will harm a certain number of innocent persons. Comment, Psychotherapists' Liability for the Release of Mentally Ill Offenders: A Propased Expansion of Strict Liability, 126 PA. L. REV. 204, 229 (1977).

213. Id. at 232 .

214. Liability imposed for negligence under the principles of professional liability will continue to compensate some victims. 